Policy Research Working Paper 1804

Financial Sector Adjustment Lending

A Mid-Course Analysis

Robert J. Cull

\section{WPS 1804}

Given a minimum acceptable level of macroeconomic. stability, postintervention financial deepening can be associated with either favorable initial conditions or successful institutional strengthening, or both, although the most despening has occurred where initial conditions were good.

The World Bank

Development Research Group

August 1997 


\section{Summary findings}

Nearly 100 countries have experienced bank insolvencies in the past 20 years. Weakness in the financiai sectors of many countries is ceflected in the size of the insolvencies - in many cases, the cost of bailour exceeded 15 perceni of CDP - and the fact that these crises often recur. Because a strong financial sector is important for economic growth, the World Bank has increasingly granted loans with conditions attached to achieve sperific fimancial secror reforms.

The Bank often enploys financia! sector adjustment loans (FSALs) or, in poorer countries, credits (FSACs). FSALs are generally more comprehensiye than other types of interyentions and tend to concentrate on the reform areas most closely linked to the operations of deposit banks. Since 1990, their main focus has shifted from improving prudential regulations and correcting interest rate distortions to privacizing and recapicalizing banks.

Cull exmmes whether ( 1 ) initial conditions in a reciplene county explan a subsiantial amount of the variation in interventon outcones (as measured by postinteryencion financial depening) and (2) whether the changing nawure of interventions has had implications for their sticcess. He finds that:

- The decline in post-interyention performance sirce 1990 cannot be atributed solely to initial macrocconomic and financial sector conditions in the recipient country.
- When initial macrocconomic and financial sector conditions were controlied for, certain types of reform, especially those dealing with prudential regulations, were associated with relatively large increases in the ratio of money supply (M2) to GDP. Those dealing with recapitalization have also been relatively successful, especially when they also tackled prudential regulation or baniking supervision. Those that focused on supervision did nor, on average, substantially outperform those that did not focus on supervision. And reform focused on bank privatization was associated with much less financial deeping three years after the intervention.

- In addition to reform aimed at institutional strengthening, the reform environment itself had a substantial impact on intervention outcomes. Financial deepening was positively associated with macroeconomic siablity (low inflation) and an initially underdeveloped financial sector.

- As the Bank's operational directives suggest, some macroeconomic stability is important for the success of financia! seccor interventions, especially those that incorpcrate interest rate liberalization.

While it may be best to move more aggressively on financial reform when macroeconomic circumstances are favorable, "visible" reform (such as privatization or interest rate dereguiation) should be slowed rather than abandonec in less forturate circumstances. By contrast, less vishle institution-building efforts should be continued regardiess of macroeconomic conditions.

This paper - a product of the Development Reseatch Group - is part of a larger effort in the group to evaluate the effectiveness of World Bank lending. Copies of the paper are available free from the Worid Bank, $1818 \mathrm{H}$ Street NW, Washington, DC 20433. Please contact Paulina Sintim-Aboagye, room N9-030, telephone 202-473-7644, fax 202-5221155, Internet address psintmaboagye@woridbank.org. August 1997. (84 pages)

The Polity Restarch Working Paper Series disseminates the findings of work in progress to encourage the exchange of ideas about development issuss. Am objective of the series is to get the findings aut quickly, even if the presentations are less than fully polished. The papers carry the nomes of the atthors and should be cited accordingly. The findings, interpreiations, and conclusions expressed in this paper are entirely those of the authors. They do not necessarily represent abe view of the World Bank, its Executive Directors, or the countries they rejresent. 
Financial Sector Adjustment Lending: A Mid-Course Analysis

Robert J. Cull

World Bank

* The findings, interpretations, and conclusions are those of the author and should not be attributed to the World Bank, its Executive Board of Directors, or any of its member countries. I thank Jerry Caprio, George Clarke, Asli Demirguc-Kunt, Phil Keefer, Ross Levine, Nicolas Mathieu, Mary Shirley, and Colin Xu for many helpful suggestions. 

The past twenty years have been witness to bank insolvencies in nearly 100 countries. Both their size -- in many cases, the cost of bail-out was greater than $15 \%$ of GDP -- and the fact that these crises often recur, reflect fundamental weaknesses in the financial sectors of many countries. ${ }^{1}$ Moreover, a growing body of evidence shows that financial sector development is important for economic growth. It should come as little surprise, therefore, that the World Bank has increasingly granted loans with conditionalities designed to achieve specific financial sector reforms. A key instrument employed by the Bank has been the Financial Sector Adjustment Loan (FSAL) or, in the case of poorer countries, Credit (FSAC). ${ }^{2}$ As described in more detail below, FSALs are generally more comprehensive than other types of financial sector interventions, and tend to concentrate on those reform areas most closely linked to the operations of deposit banks. Since 1990, their focus has shifted somewhat from improving prudential regulations and correcting interest rate distortions to bank privatization and recapitalization. This paper examines (1) whether initial conditions in a recipient country explain a substantial amount of the variation in intervention outcomes (as measured by post-intervention financial deepening), and (2) whether the changing nature of interventions have had implications for their success.

1 Caprio and Klingebiel (1996).

2 For ease of exposition, we will use "FSALs" to refer to both loans and credits. Credits are loans that carry a "concessionary" interest rate, a rate below that charged on other Bank loans. World Bank loans are administered by the International Bank for Reconstruction and Development (IBRD). Credits are handled by the International Development Association (IDA). 
Section I uses a conceptual framework and a database created by the Bank's Operations Evaluation Department (OED) to describe the characteristics of financial sector loans as they have evolved over time. Although FSALs have always tended to cover more reform areas than other Bank financial sector adjustments, their size (as measured by loan funds per resident, or as a percentage of total funds lent to that country by the Bank) has increased substantially relative to their levels in the 1980 s. That increase coincided with both greater financial insolvency problems in many countries ${ }^{3}$ and a shift in emphasis in the Bank's loan conditionalities. Whereas the FSALs of the 1980s focused primarily on incentive distortions that could be righted through legislative actions (e.g., non market-based interest rates), the emphases in the $90 \mathrm{~s} \mathrm{-} \mathrm{bank} \mathrm{privatization} \mathrm{and} \mathrm{re-}$ capitalization -- required something more. Ownership changed hands and bank capital was replenished but, unless bankers' underlying incentives changed (either through improvements in supervision or other regulation), these interventions often were ineffective in spurring financial depth in comparison with the earlier interventions.

Sections II and III, which evaluate the overall success of recent FSALs relative to both previous ones and to other types of financial sector interventions, attempt to control for factors other than the nature of the reform so as to better isolate the independent effects of changed FSAL emphasis. Section III, for example, uses regression analysis to hold constant factors such as financial sector and macroeconomic conditions at the time of the loan (including deposit bank credit to the private sector, inflation, and openness to

Caprio and Klingebiel (1996). 
international trade). ${ }^{4}$ Aside from helping to isolate the effect of the change in emphasis, these initial condition variables tell a story of their own -- recipient countries with an under-developed financial sector, low to moderate inflation, and an openness to trade experienced the most financial deepening in the wake of a loan. Importantly, however, controlling for initial conditions, loans that emphasized bank privatization exhibited less post-loan deepening than those that emphasized other areas. In addition, loans that emphasized bank re-capitalization but did not also focus on improved prudential regulations were linked with somewhat less deepening than those loans that did both.

Because the Bank undertook many of its financial sector interventions in the past few years, it is premature to evaluate many of these loans. As a result, the number of observations available for the regressions was small. To examine the reliability of the regression results, therefore, section IV analyzes four specific cases -- Pakistan, the Philippines, Tanzania, and Venezuela. The cases underscore the importance of initial conditions in the outcomes of financial sector loans. In addition, however, there is some evidence of the independent effect of the type of reform on the level of post-loan financial deepening. In short, the cases provide reasonable support for the regression results. Finally, section $V$ concludes and offers recommendations as to best practice.

All three variables are measured as a percentage of GDP. 


\section{FSAL Characteristics}

\section{(A). Types of Reform}

Reform identification in this paper is based on a recent OED methodology to identify the presence or absence of policies in Bank-assisted financial sector reform programs across countries. ${ }^{5}$ OED classified financial sector policies in sixteen broad categories. The categories, which OED grouped according to their major objectives, are given below:

(a) Removal of Distortions:

Interest rate liberalization

Indirect monetary instruments

Dismantle directed credit

Capital account liberalization

(b) Increased Competition

Bank privatization

Competition laws

Differential taxation/regulation of banks

Foreign ownership laws

(c) Improved Financial System Infrastructure

Central Bank law

Prudential regulations, banking law

Non-bank regulations

Money market ${ }^{6}$

Rights and obligations of financial agents

(d) Strengthening of Individual Financial Institutions

Bank supervision

Bank re-structuring-re-capitalization

Bank institutional reforms

5 See Financial Sector Reform: A Review of World Bank Assistance, OED, preliminary draft, February, 1997. I am deeply indebted to OED and, in particular, Nicolas Mathieu, for providing the data that summarizes the individual interventions. Without it, this project would not have been possible.

$6 \quad$ Although the OED draft does not explicitly state that there is no overlap between the "money market" category and "indirect monetary instruments," it appears that the categories are mutually exclusive. 
To date, OED has applied this methodology to eighty-five 'adjustment related operations' (including twenty-four FSALs) in fifty-six countries. This analysis examines the effect of these policy variables on financial sector outcomes (in particular, deepening as measured by M2/GDP) for the most recent operation in each country. ${ }^{7}$ In this way, one can also test whether prior operations had a positive effect on current ones. Of the fiftysix potential observations, however, less than half typically enter into the analysis presented here because sufficient time has not yet elapsed since the project's inception to evaluate the outcomes.

For the purposes of this research, however, the OED classification procedure carries some limitations. For example, OED considered a reform to have been attempted largely on the basis of the objectives (summarized in the policy matrix) stated in the President's Report that accompanied each loan. The matrix was, however, an ex-ante

7 Lack of time series data for other financial measures compels the reliance on general measures of financial depth (e.g., M2) in assessing the outcomes of these loans. This is unfortunate because the loans presumably had more objectives than increasing depth. For example, Levine (1996) highlights five main functions of a financial system -to facilitate the trading, hedging, diversifying, and pooling of risk; to allocate resources; to monitor managers and exert corporate control; to mobilize savings; and, finally, to facilitate the exchange of goods and services. Improvements in these five areas are only indirectly and imperfectly captured by changes in financial depth. Indeed, a complete analysis of the effects of financial sector adjustment loans would likely require a different set of dependent variables for each of the five functions described above.

OED has made a serious attempt to move beyond M2/GDP, creating several financial sector and banking system time series, but data discontinuities do not yet allow econometric analysis. A minimal dataset would include, for three years prior to and after each FSAL, comparable data on financial deepening, banking supervision (number of salaries, number of supervisors, etc.), portfolio quality in the banking system, and prevailing interest rates. This standard template would greatly facilitate analysis of the Bank's financial sector interventions. 
indication of planned reform, not necessarily an ex-post measure of actual reform. During the course of a loan, plans may change. Some reforms are scrapped; others are altered. In Pakistan's FSAL, for example, a major component was the restructuring of many stateowned banks. Upon implementation, the Government decided that its restructuring efforts would be less effective than bank privatizations. Although the Bank later applauded the shift in emphasis, ${ }^{8}$ the OED classification indicates that the Pakistan FSAL attempted restructuring but not privatization. Of course, that classification may be partially accurate in that, although Pakistan's was a 1989 FSAL, little privatization had occurred as of $1996 .^{9}$ The episode underscores two problems with the reform data -- although planned reform is different than actual reform, and substantial reform is different than minor reform, those differences are sometimes difficult to capture in simple dummy variables which are based largely on the expressed intentions of the parties to these loans. That said, to the extent that expressed intentions are reliable indicators of ensuing reform and that the Bank's loan documentation adequately summarizes those intentions, the measurement error associated with the OED variables should not be debilitating. Indeed, given the judgments that ex-post reform variables would have entailed (What form did privatization take? Was the re-capitalization sufficient? Were prudential regulations

8 World Bank, "Pakistan FSAL: Project Completion Report," March 16, 1995, pp. 6-11.

9 More generally, the privatization policy category identified by OED is broadly defined and does not permit one to determine what form eventual privatizations took. Data on what assets were sold to whom and at what price were not available in a systematic format, although OED's project audit reports did provide good information in some cases. 
adequately strengthened?), OED's reliance on ex-ante reform dummy variables was sensible.

\section{(B). Changed Emphasis in Financial Sector Adjustment Lending}

In the early 1990s financial sector adjustment lending, in particular FSALs, became far more prevalent than in the ' 80 s. In addition, loan size -- measured in dollars lent per resident or as a percentage of a recipient country's total World Bank loan portfolio -increased substantially (See Appendix 2 for details). A shift in emphasis coincided with the elevated importance of FSALs, which is reflected in the percentage of interventions that incorporated each reform area (Table 1.1). With respect to changes over time, the reform areas can be separated into four categories: (1) those that were points of emphasis prior to 1990 that became even more prevalent thereafter, (2) those that were emphasized early on that became somewhat less important in the latter period, (3) those that were not emphasized in the early period that became substantially more so later on, and (4) those that were not particularly emphasized in either period. Among the two reform areas in the first group, bank re-capitalization was the most prevalent. In the earlier period, three of four FSALs had a re-capitalization component; in the latter, $86 \%$ of them did. Similarly, bank supervision, although not neglected in the early period ( $63 \%$ inclusion rate), became a component in $79 \%$ of the latter FSALs. Clearly, this first group is comprised of two reform areas of substantial importance to the Bank. 


\begin{tabular}{|c|c|c|c|}
\hline \multicolumn{4}{|c|}{$\begin{array}{c}\text { Table 1.1 } \\
\text { Changes in FSALs Over Time } \\
\text { (Braken Down By Reform Area) }\end{array}$} \\
\hline Reform Area & $\begin{array}{l}\text { Probability of Inclusion } \\
\text { Post-1990 }\end{array}$ & $\begin{array}{l}\text { Probability of Inclusion } \\
\text { Pre-1990 }\end{array}$ & Change \\
\hline $\begin{array}{l}\text { Group I } \\
\text { Bank Re-Capitalization } \\
\text { Bank Supervision } \\
\text { Group II } \\
\text { Prudential Regulations } \\
\text { Non-Bank Regulations } \\
\text { Interest Rate Distortion } \\
\text { Ind. Monetary Control } \\
\text { Group II } \\
\text { Bank Privatization } \\
\text { Other Bank Ins. Reform } \\
\text { Group IV } \\
\text { Directed Credit } \\
\text { Differential Bank Reg. } \\
\text { Central Bank Law } \\
\text { Rights/Obs. Fin. Agents } \\
\text { Companies Law } \\
\text { Liberalize Capital Acct. } \\
\text { Money Market Dev. } \\
\text { Foreign Ownership }\end{array}$ & $\begin{array}{l}50 \% \\
43 \% \\
\\
\\
29 \% \\
29 \% \\
29 \% \\
21 \% \\
14 \% \\
14 \% \\
0 \% \\
0 \% \\
\\
N=8\end{array}$ & $\begin{array}{c}13 \% \\
13 \% \\
\\
\\
38 \% \\
38 \% \\
25 \% \\
38 \% \\
25 \% \\
0 \% \\
13 \% \\
0 \% \\
\\
\mathrm{~N}=14\end{array}$ & $\begin{array}{c}-9 \% \\
-9 \% \\
+4 \% \\
-17 \% \\
-11 \% \\
+14 \% \\
-13 \% \\
0 \%\end{array}$ \\
\hline
\end{tabular}

No doubt, the second group also contains reform areas that were and are of substantial import to the Bank. However, each of these areas lost some ground to supervision and re-capitalization in the latter period. Prudential regulations, non-bank regulations, and interest rate distortions all had a probability of inclusion greater than $75 \%$ in the early period but not in the latter. Indirect monetary control remained at $50 \%$ across both periods, and thus was more difficult to classify. While that area wasn't neglected in 
FSALs, it wasn't emphasized as heavily as the other reform areas in groups one and two. For purposes of this paper we refer to those reform areas in group one as being in their ascendancy; those in group two (excluding indirect monetary control) as being in decline (although clearly still important). Those in group three are also in ascendancy, although their probability of inclusion in the latter period still ranks below that of groups one and two. We make a distinction between the two areas in group three -- bank privatization and other bank institutional reforms. Because privatization only applies to FSALs in countries where banks were publicly owned, and the probability of inclusion is calculated over all FSALs, the figures in Table 1.1 likely understate this area's importance. By contrast, it is difficult to argue that the relatively nebulous "other bank institutional reform" category is not potentially relevant for all FSALs. It seems safe to conclude, therefore, that privatization was more heavily emphasized by the Bank than was other bank institutional reform, especially in later FSALs. As a result, in the remainder of the paper, privatization joins re-capitalization and supervision in the ascending group. Prudential regulations, non-bank regulations, and interest rate distortions are in the descending (but emphasized) group. Indirect monetary control and other institutional reforms are grouped with those reforms that were not particularly important in either period -- directed credit, differential bank laws, central bank laws, capital account liberalization, money market development, and foreign ownership. ${ }^{10}$ While each of these

10 A case could be made that, much like the privatization category, the figures in Table 1.1 may understate the importance of areas such as directed credit. That is, the category is only relevant for FSALs in countries that had directed credit problems, but the probability of the reform area's inclusion in an operation is computed over all FSALs. Privatization is, however, separated from these others for two reasons. First, its post1990 inclusion rate is higher (or as high in the case of indirect monetary control) than that 
categories may have been especially important in a particular intervention, none of them is, on average, particularly characteristic of FSALs. The focus of the analysis is, therefore, on the six reform areas in the ascending and descending groups.

The changed emphasis in FSALs was not shared by non-FSAL financial sector lending operations (hereafter non-FSALs) as the two have become increasingly distinct developmental tools for the Bank (See Appendix 3 for details). FSALs have always been substantially focused on reforms related directly to banks' capital structure and operations (re-capitalization, supervision, prudential regulations, and interest rate distortions) or indirectly to banks through their primary competitors (non-bank regulations). ${ }^{11}$ Emphasis on capital structure and governance, moreover, has been further underscored by the emergence of privatization as a significant reform area. As noted, however, within this group of bank reform areas, some have come to be increasingly dominated by FSALs (privatization, re-capitalization, and supervision), others slightly less so (prudential regulation and non-bank regulation). Although there appears to be no obvious qualitative distinction that can explain the emergence of the two groups, it does appear that successful reform in the ascending group may be more difficult to achieve than in the descending group -- those in the latter group are largely legislative reforms while those in

of all of the "not emphasized" reform areas. Second, privatization exhibited a large increase from one period to the next. The majority of those areas in the not emphasized group experienced declines ranging from nine to seventeen percent. Among those that had an increase, only "other bank institutional reform" had one that came close to the increase in privatization. To separate privatization from this group, therefore, does not appear to be misleading.

11 See Appendix 4 for additional summary data on the relative importance of reform areas for FSALs and non-FSALs across both periods. 
the former may require substantial institution building within banks to be successful. It is also clear that reform areas pertaining to financial actors not closely related to banks (financial agents) or to reforms that have a less direct effect on bank operations (companies laws) increasingly have become the province of non-FSALs.

In summary, the nature of FSALs has changed over time. Although their focus is concentrated in the same areas, the relative importance of reform types has changed in favor of privatization, re-capitalization, and supervision. In addition, non-FSAL financial sector interventions have exhibited very different changes. Increasingly, their emphasis has shifted to areas not emphasized by FSALs, those less intimately connected to banks' operations including the rights and obligations of financial agents, companies laws, and money market development. Does their more comprehensive nature or differential focus have implications for the success of FSALs relative to other types of financial interventions? Moreover, has the increased emphasis on potentially more tedious reform areas had implications for the success of FSALs, at least regarding short term benefits? It may, for example, be difficult to privatize and re-capitalize banks while making major revisions to supervision, all within the context of a quick-disbursing FSAL. We address these issues in the next section.

\section{Performance of FSALs: Summary Statistics}

\section{(A). FSALs vs. Non-FSALs, Broken Down by Period}

The summary statistics indicate that, on average, the Bank realized greater improvements in the banking sector when it tailored loans specifically to financial sector 
adjustment through FSALs as opposed to including financial sector components in non-

FSALs (See Appendix 5 for summary statistics for the entire period 1985-95). FSALs did not, however, outperform non-FSALs over the entire period - post-1990 FSALs were no more successful than non-FSALs (Table 2.1). In terms of post-intervention improvements in M2, liquid liabilities, and deposit bank credit to the private sector as percentages of GDP (M2/GDP, LL/GDP, and DBPC/GDP, respectively), pre-1990 FSALs substantially outperformed both later ones and non-FSALs from either period. ${ }^{12}$ Although pre-1990 non-FSALs appear to have been the least effective subset -"improvements" on the three measures hovered between zero and one percent in absolute value, often with the incorrect sign -- post-1990 interventions (both FSALs and nonFSALs) were not substantially better. The relatively large average improvement in M2/GDP in the wake of post-1990 FSALs (+3.1\%) is driven by one observation, Tanzania $(+8.9 \%)$. After eliminating it from the sample, the average improvement in M2/GDP was only $1.17 \%$, a figure quite similar to those for non-FSALs. Similarly, the relatively large improvement in M2/GDP and LL/GDP that was associated with post-1990 non-FSALs was driven heavily by Nicaragua. Ignoring that observation, the average improvements in

12 Admittedly, small sample problems make the averages in Table 2.1 somewhat less reliable than one might like. The source of the DBPC, M2, LL, and GDP data is the IMF's International Financial Statistics Yearbook (1996). DBPC includes all assets of deposit money banks classified as claims on the private sector. M2 includes the sum of all currency held outside of banks, demand deposits other than those of the central government, and time, savings, and foreign currency deposits of "resident sectors other than the central government." Liquid liabilities include M2 plus demand and interest bearing liabilities of non-bank financial intermediaries such as savings banks, postal savings institutions, and finance companies. In the individual country data, DBPC data are reported on line 22d, M2 data on line 351, and LL data on 551 . 
M2/GDP and LL/GDP were $.62 \%$ and $.90 \%$, respectively -- figures substantially similar to those for pre-1990 FSALs. ${ }^{13}$

Table 2.1

Changes in Performance Indicators Over Time, FSALs and Non-FSALs

\begin{tabular}{|l|c|c|c|c|}
\hline \multicolumn{1}{|c|}{ Indicator } & \multicolumn{2}{|c|}{ FSALs } & \multicolumn{2}{c|}{ Non-FSALs } \\
& $\begin{array}{c}\text { Pre-1990 } \\
\text { (\% Change, 3 Yrs. } \\
\text { After Intervention) }\end{array}$ & $\begin{array}{c}\text { Post-1990 } \\
\text { (\% Change, 3 Yrs. } \\
\text { After Intervention) }\end{array}$ & $\begin{array}{c}\text { Pre-1990 } \\
\text { (\% Change, 3 Yrs. } \\
\text { After Intervention) }\end{array}$ & $\begin{array}{c}\text { Post-1990 } \\
\text { (\% Change, 3 Yrs. } \\
\text { After Intervention) }\end{array}$ \\
\hline & & & & \\
As a \% of GDP: & & & & \\
M2 & $+5.43(6.41)^{*}$ & $+3.09(5.46)$ & $-1.17(4.30)$ & $+2.78(7.25)$ \\
Liquid Liabilities & $+6.32(6.90)$ & $-0.25(7.12)$ & $+1.03(2.10)$ & $+4.47(8.74)$ \\
Dep Bank Pr Cred & $+4.38(8.43)$ & $-0.23(5.66)$ & $-0.48(2.02)$ & $+0.45(11.3)$ \\
Non Bank Pr Cred & $-0.04(1.35)$ & $-1.14(1.68)$ & $-0.66(1.26)$ & $+0.19(0.49)$ \\
Cen Bank Pr Cred & $-0.06(0.19)$ & $-0.04(0.08)$ & $-1.97(3.66)$ & $+0.001(.003)$ \\
Fixed Cap. Form. & $+0.06(2.14)$ & $+3.84(5.83)$ & $+0.93(2.72)$ & $-0.28(4.69)$ \\
& & & & \\
As a \% of GDP & & & & \\
(Outliers & & & & \\
Omitted) & & & & \\
& & & & \\
M2 & & +1.17 & -1.17 & +0.62 \\
Liquid Liabilities & +5.00 & -0.25 & +1.03 & +0.90 \\
Dep Bank Pr Cred & +2.22 & -0.23 & -0.48 & +0.45 \\
Non Bank Pr Cred & -0.04 & -1.14 & -0.66 & +0.19 \\
Cen Bank Pr Cred & -0.06 & -0.04 & -0.48 & +.001 \\
Fixed Cap. Form & +0.06 & +0.19 & +0.93 & +0.28 \\
\hline
\end{tabular}

* Standard Deviations in Parentheses

The only remaining performance indicators that do not tip in favor of pre-1990

FSALs are the average improvement (that is, decline) in central bank credit to the private sector as a percentage of GDP (CB/GDP), which favors pre-1990 non-FSALs, and the figure for fixed capital formation relative to GDP (FCF/GDP), which favors post-1990

13 The average improvements associated with pre-1990 FSALs are, of course, also sensitive to individual observations. Excluding the largest observed improvement from the calculation (namely Mexico, whose improvement on these measures ranged from 14$20 \%$ ), the average change for pre-1990 FSALs in M2/GDP, LL/GDP, and DBPC/GDP was $4.13 \%, 5.00 \%$, and $2.22 \%$, respectively. These figures are substantially higher than the corrected figures for post-1990 FSALs and all non-FSALs.

14 As discussed in the text. 
FSALs. Similar to other figures for post-1990 FSALs, FCF/GDP is heavily influenced by two observations, Peru and Rwanda (9.4\% and 9.3\%, respectively) ${ }^{15}$ After removing those, the FCF/GDP improvement drops to $0.19 \%$, which is similar to that for pre- 1990 FSALs. It is puzzling that the banking indicators perform relatively well for pre-90 FSALs relative to the other three subsets of interventions while FCF/GDP improvements are relatively comparable (and meager). One possible explanation is that, because FCF data was not available for as many countries as was M2 and DBPC data, the average improvement figures may be less reliable than the others. Alternatively, FCF/GDP may measure something quite distinct from financial sector development as measured by, say, DBPC/GDP. In particular, improvements in indicators that measure relatively liquid assets (DBPC) may precede those for indicators that measure illiquid assets (FCF).

With respect to reducing central bank credit to the private sector, pre-1990 nonFSALs performed better than other interventions. That result is, to some extent, also driven by one observation (Chile, $-8.4 \%$ ). ${ }^{16}$ Even after correction, however, the improvements are somewhat more pronounced for pre-90 non-FSALs than for the other subsets $(-0.48 \%) .{ }^{17}$ However, like the FCF/GDP indicator, the CB/GDP improvement may not measure precisely what was desired. For most of the countries in the sample, central bank credit to the private sector was at or near zero at the time of intervention.

is No other countries in the sample exceeded $5 \%$ improvement on this measure. 16 No other country in the sample had a CB/GDP figure higher than $1.0 \%$ at the time of the intervention.

17 Indeed, central bank law was a point of emphasis for non-FSALs prior to 1990 (see Appendix 3). 
These countries could not, therefore, reduce CB/GDP. The improvement for pre-1990 non-FSALs may merely be an indication that the handful of countries with room to improve on this measure (i.e., substantial central bank credit to the private sector) were grouped in this particular subset. Indeed, when one looks only at those countries that had moderately high levels of central bank credit to the private sector at the time of the intervention (between 0.3 and 1.0\%), the improvements for the four subsets become much more similar, and pre-1990 FSALs again outperform all others $(-0.54 \%$ for pre-90 FSALs, $-0.17 \%$ for post-90 FSALs, $-0.48 \%$ for pre- 90 non-FSALs, and +.001 for post- 90 nonFSALs). To summarize, CB and FCF measurement problems aside, pre-1990 FSALs were the most effective subset of interventions in terms of banking sector development especially as reflected in M2, liquid liabilities, and deposit banks' credit to the private sector. For Post-1990 FSALs and non-FSALs, most of the average changes in these indicators were so small as to be attributable to noise, which raises the possibility that the operations have had no impact, or that it make require more than three years for improvements to take hold. The remainder of the paper explores (1) why other types of interventions generally fared worse than early FSALs, and (2) whether the shift in FSALs' emphasis described in section I played a role in their relatively poor performance after 1990.

\section{(B). Post-Intervention Performance and Initial Conditions in the Recipient Country}

To isolate the effect of the change in project emphasis on post-intervention improvement, other relevant factors must be held constant. Among the most important are, perhaps, initial conditions. Although, on average, initial conditions did not vary 
substantially across FSALs and non-FSALs (and thus the differences in average

performance cannot be easily attributed to them), the success of individual interventions was quite sensitive to them. ${ }^{18}$ In particular, improvements were largest in those countries that had a relatively stable macroeconomic environment and a relatively under-developed financial sector at the time of the intervention. For example, in countries with relatively "low" inflation (less than 25\%) and insubstantial financial sector development (DBPC/GDP less than 20\%), the average improvement in M2 was $6.37 \%$ three years after intervention. In high-inflation, low financial development countries (inflation greater than $25 \%$, DBPC/GDP less than $20 \%$ ), improvements were much smaller $(+3.71 \%) .{ }^{19}$ In high financial development countries, "improvements" were even smaller. High-development, low-inflation countries (Group III) experienced reductions in M2/GDP (-0.74\%). Worse yet, the average improvement for Group IV (high development, high inflation countries) was $-3.92 \%$. The M2 improvement breakdowns indicate clearly that interventions have fared best in countries with relatively low initial inflation and under-developed private banking sectors. ${ }^{20}$ The predictability of post-intervention outcomes, moreover, appears

18 See Appendix 6 for additional details on initial conditions in countries receiving FSALs vs. non-FSALs.

19 If the largest observation is dropped from each of these categories, the differences become even more pronounced -- Group I countries averaged a $6.24 \%$ improvement; Group II countries $1.55 \%$. These figures remain higher than those for Group III and IV countries.

20 Of course, the number of observations in each of these groups is quite small, so the statistical significance of differences in means is suspect. Also, the use of DBPC/GDP as a measure of financial sector development may, in some instances, be misleading -- in countries with predominantly publicly-owned deposit banks, a high DBPC/GDP figure may merely indicate a substantial amount of credit directed to government allies in the private sector. We might expect such countries to experience less financial deepening after an intervention. In general, however, we assume that these problems are not severe 
to be much lower for countries experiencing high inflation as indicated by the relatively

high standard deviations on the average improvement measures.

\begin{tabular}{|c|c|c|c|c|}
\hline \multicolumn{5}{|c|}{$\begin{array}{l}\text { Table } 2.2 \\
\% \text { Changes in Performance Indicators, All Financial Sector Adjustments } \\
\text { Controlling for Initial Macroeconomic And Financial Sector Conditions }\end{array}$} \\
\hline & \multicolumn{4}{|c|}{$\begin{array}{c}\text { Macroeconomic and } \\
\text { Financial Sector Conditions }\end{array}$} \\
\hline Indicator & $\begin{array}{c}\text { Group I } \\
\text { Inflation }<25 \% \\
\text { Dep Bank Pr Cred } \\
<20 \% \text { of GDP } \\
\end{array}$ & $\begin{array}{l}\text { Group I } \\
\text { Inflation }>25 \% \\
\text { Dep Bank Pr Cred } \\
<20 \% \text { of GDP }\end{array}$ & $\begin{array}{c}\text { Group III } \\
\text { Inflation }<25 \% \\
\text { Dep Bank Pr Cred } \\
>20 \% \text { of GDP }\end{array}$ & $\begin{array}{c}\text { Group IV } \\
\text { Inflation }>25 \% \\
\text { Dep Bank Pr Cred } \\
>20 \% \text { of GDP } \\
\end{array}$ \\
\hline As a \% of GDP: & & & & \\
\hline $\begin{array}{l}\text { M2 } \\
(\mathrm{M} 2 / \mathrm{GDP})\end{array}$ & $\begin{array}{c}+6.37(3.86)^{*} \\
N=6\end{array}$ & $\begin{array}{c}+3.71(7.15) \\
N=6\end{array}$ & $\begin{array}{c}-0.74(3.36) \\
\quad N=7\end{array}$ & $\begin{array}{c}-3.92(5.88) \\
\mathrm{N}=2\end{array}$ \\
\hline $\begin{array}{l}\text { Liquid Liabilities } \\
\text { (LL/GDP) }\end{array}$ & $\begin{array}{c}+7.21(3.99) \\
N=5\end{array}$ & $\begin{array}{c}+2.09(7.88) \\
\quad N=5\end{array}$ & $\begin{array}{c}-1.04(3.68) \\
N=4\end{array}$ & $\begin{array}{l}(-) \\
N=0\end{array}$ \\
\hline $\begin{array}{l}\text { Dep Bank Pr Cred } \\
\text { (DBPC/GDP) }\end{array}$ & $\begin{array}{l}+3.47(5.27) \\
\quad \mathrm{N}=7\end{array}$ & $\begin{array}{c}+3.26(9.09) \\
N=6\end{array}$ & $\begin{array}{c}-0.39(4.82) \\
N=7\end{array}$ & $\begin{array}{c}-7.20(12.89) \\
N=2\end{array}$ \\
\hline $\begin{array}{l}\text { Non Bank Pr Cred } \\
\text { (NB/GDP) }\end{array}$ & $\begin{array}{c}+0.31(1.02) \\
N=7\end{array}$ & $\begin{array}{c}-1.17(1.66) \\
N=6\end{array}$ & $\begin{array}{c}-0.50(1.26) \\
\mathrm{N}=6\end{array}$ & $\begin{array}{c}0.00(0.00) \\
N=2\end{array}$ \\
\hline $\begin{array}{l}\text { Cen Bank Pr Cred } \\
\text { (CB/GDP) }\end{array}$ & $\begin{array}{l}+0.15(0.04) \\
\quad N=7\end{array}$ & $\begin{array}{c}-0.12(0.22) \\
N=6\end{array}$ & $\begin{array}{c}-1.20(3.17) \\
\quad N=7\end{array}$ & $\begin{array}{c}-0.51(0.89) \\
\quad \mathrm{N}=3\end{array}$ \\
\hline $\begin{array}{l}\text { Fixed Cap. Form. } \\
\text { (FCF/GDP) }\end{array}$ & $\begin{array}{l}+0.28(4.57) \\
\quad \mathrm{N}=8\end{array}$ & $\begin{array}{c}+0.96(5.13) \\
\mathrm{N}=6\end{array}$ & $\begin{array}{l}+0.85(2.81) \\
\quad \mathrm{N}=7\end{array}$ & $\begin{array}{l}+0.31(0.57) \\
\quad \mathrm{N}=2\end{array}$ \\
\hline
\end{tabular}

* Standard Deviations in Parentheses

The inflation results should come as no surprise, as the banking sector is less apt to grow when savers, borrowers, and bankers face dramatic currency volatility. The financial development results are, however, less intuitive. Apparently, we can expect better developed financial sectors to grow more slowly as they approach an "appropriate" level

and that DBPC/GDP is, in most instances, a reasonable indicator of financial sector development.

21 As described below, due to data measurement problems, Nicaragua was excluded from the regression results and from the M2/GDP, DBPC/GDP, and FCF/GDP figures for group IV. See fn. 34. 
relative to GDP. ${ }^{22}$ These results are, moreover, robust across the other indicators. The liquid liabilities results closely mirror those for M2 development. Those for deposit bank credit are also quite similar, except that, among less financially developed countries, the disparities between those with high and low inflation are less pronounced -- low-inflation had $3.47 \%$ average improvements, high-inflation $3.26 \%$. The standard deviation for the high inflation countries was, however, large relative to that for low-inflation countries, yet further indication of the hit-or-miss nature of adjustment in high inflation countries. The DBPC/GDP "improvements" for countries with better-developed financial sectors were dismal, especially for those that simultaneously experienced high inflation (-7.2\%).

Perhaps because banks were the focus of the financial sector operations studied here, credit issued by non-bank financial intermediaries improved little (if at all), irrespective of initial conditions. With respect to central bank credit to the private sector, countries with better-developed financial sectors experienced larger reductions than others. This appears to be the only indicator that tips clearly in favor of the better-developed, although, given the potential measurement problems associated with CB/GDP described above, that victory may be illusory. Finally, with respect to fixed capital formation improvements, the disparities between subsets are small. Again, FCF/GDP, a measure of relatively illiquid assets, does not display the cross-group distinctions of the other indicators of financial depth.

In short, initial conditions appear to have had implications for the success of Bank interventions. The data indicate that the most substantial improvement has typically

22 We discuss a possible theoretical rationale for this result in the next section. 
occurred in countries with both stable macroeconomic environments and under-developed banking systems. ${ }^{23}$ However, because initial conditions were, on average, very similar across intervention types, it is unlikely that they can be solely responsible for early FSALs' relative success. More likely candidates include either the nature of the reform or the extent of institutional development in the recipient country (competence of bank supervisors, enforceability of contracts, etc.). In addition, it may be that, even after controlling for all of these factors, FSALs are somehow different from other financial sector interventions. Perhaps the Bank allocates resources differently when it devotes an entire project to financial sector reform as opposed to incorporating financial components in more general adjustment loans as it did in many non-FSALs. In the next section, we use simple regression analysis to control for all of these factors -- initial conditions, reform areas covered, institutional development, and intervention type (FSAL vs. non-FSAL).

\section{Regression Analysis}

\section{(A). Hypotheses}

Regression analysis is included here for two reasons -- to control simultaneously for institutional, sectoral, and macroeconomic conditions in summarizing the results of the Bank's financial sector interventions and to help select the most telling cases, which will be discussed in further detail in the next section. Among the variables used to explain intervention success is openness to international trade which is often linked to economic

23 Again, however, these differences in means are less reliable than one might like due to the small number of observations in each group. 
growth. ${ }^{24}$ To the extent that openness contributes to growth that increases borrowers' net worth, one would expect these improvements in the real sector to be reflected in the growth of the banking sector. Gertler and Rose argue cogently that, in a world of informational asymmetry, borrower net worth is at the core of the link between finance and aggregate economic activity. ${ }^{25}$ Because greater net worth increases a borrower's potential stake in an investment, incentives are aligned more closely between borrower and banker thus reducing the premium on funds. As a result, the banking sector expands.

Also, to the extent that openness diversifies some risks that an economy faces regarding input or output prices, we might expect it to be less susceptible to the internal shocks that cause large declines in borrower net worth in relatively closed economies. ${ }^{26}$ All else equal, therefore, we expect openness as measured by exports or imports as a percentage of GDP (EXP/GDP or IMP/GDP, respectively) to be positively related to growth in the financial sector. $^{27}$

24 From the numerous cross-country studies of economic growth, one robust finding is that, holding other relevant factors constant, there is a positive correlation between the share of investment in GDP and the average share of trade in GDP. Investment share, in turn, is positively and robustly correlated with average growth rates. A possible intuition underlying this result is that openness to international markets enhances productivity by encouraging specialization that would be unprofitable in smaller markets. Levine and Renelt (1992), p. 953. Levine and Renelt review a number of cross-country growth regression analyses. Many including Kormendi and Meguire (1985), Barro (1991), and Romer (1990) also find strong correlations between investment and growth. On the link between outward orientation and growth in developing countries, see Doilar (1992) and Pritchett (1991).

25 Gertler and Rose (1994), p. 28.

26 Of course, an open economy would be more susceptible to external shocks. The implicit assumption, therefore, is that the diversification opportunities afforded by openness result in shocks that are, on average, smaller than those faced by an identical, but closed economy.

27 As Levine and Renelt are quick to point out, findings regarding EXP/GDP and investment, or EXP/GDP and growth can also be obtained almost identically using total 
The growth literature points to an additional explanatory variable that we should consider: initial real income per capita. The convergence hypothesis, as it has come to be known, holds that a poor country tends to grow faster than a rich one. The underlying theoretical intuition is that, given a decreasing marginal product for capital, rich countries receive less growth per unit of additional investment than do poor ones. One would expect that, for a given level of additional investment, poorer countries would "catch up" to richer countries. In this way, real incomes in different countries should tend to converge. While there is little empirical support for unconditional convergence, ${ }^{28}$ a number of researchers have found support for conditional convergence. That is, there is a robust negative partial correlation between initial income in a country and real GDP growth, but only if other relevant factors such as investment (as a share of GDP) are held constant. ${ }^{29}$ The result may have implications for the development of the financial sector. Gertler and Rose find strong evidence that countries with higher income (and thus higher borrower net worth) have deeper financial systems. ${ }^{30}$ We would expect, therefore, that countries with high per capita income at the time of an intervention would also have relatively well-developed financial systems as measured by DBPC/GDP (one of the initial

trade or import share measures. As a result, "studies that use export indicators should not be interpreted as studying the relationship between growth and exports per se but rather as studying the relationship between growth and trade defined more broadly." Levine and Renelt (1992), p. 959.

28 See DeLong (1988) and Romer (1987). Pritchett (1995) estimates that the ratio of the incomes of the richest to the poorest countries increased at least sixfold between 1870 and today.

29 See Barro (1991), Mankiw et al. (1992), and Levine and Renelt (1992).

30 Gertler and Rose (1994), p. 40. 
conditions from Section II). As a result, initial GDP per capita and DBPC/GDP may perform similar roles in explaining real sector growth which, if Gertler and Rose are to be believed, should be linked to the post-intervention development of a country's financial system. We might, therefore, expect a negative partial correlation between postintervention financial sector development and either initial DBPC/GDP or initial per capita GDP. Inflation, the other initial condition from Section II, is, of course, also expected to have a negative partial correlation with financial development. With respect to initial conditions, therefore, explanatory variables will include the inflation rate, trade variables (EXP/GDP or IMP/GDP), and DBPC/GDP or real GDP per capita, all measured in the year of the intervention.

More recent research on growth has emphasized the important role that institutions may play. In particular, both real GDP growth and investment rates have been linked to the quality of a country's institutions. The Gertler-Rose hypothesis suggests that any income growth, even if born of institutional development, should also be reflected in deeper financial systems. In the regressions that follow we would, therefore, expect a positive partial correlation between post-intervention financial sector development and institutional development. To measure institutional quality in the recipient country, we use indices created by Knack and Keefer based on indicators compiled by two private international investment risk services, the International Country Risk Guide (ICRG) and Business Environmental Risk Intelligence (BERI). ${ }^{31}$ The Knack and Keefer indices are

$31 \quad$ Knack and Keefer (1995), pp. 225-6. 
averages of a number of indicators including quality of the bureaucracy, corruption in government, the rule of law, government expropriation risk (of private property), contract enforceability, and infrastructure quality. Descriptions of the individual indicators and additional details regarding the construction of the indices are found in Appendix 7. While none of the indicators deal with financial issues per se, each may provide some indication of the stability that lenders and borrowers might expect within the financial system. For example, bank supervision may be best in countries whose bureaucratic quality is high. Similarly, corrupt governments may be more likely to direct credit on a non-market basis to preferred personal uses, and to build up large arrears. Governments that repudiate contracts, expropriate property, and do not follow the rule of law, moreover, may be more willing to enact policies that seriously alter the value of deposits and loans (e.g., through abrupt currency devaluations, or unpaid deposit insurance claims in the event of bank failures). In turn, depositors (and lenders) that expect arbitrary treatment from their government may be less likely to channel investable resources through formal intermediaries. In short, while these are, of course, not perfect indicators, the indices may provide a reasonable measure of institutional stability in the financial sector. Like the initial macroeconomic and financial sector conditions, institutional conditions are measured in the year of the intervention.

The remaining explanatory variables are also institutional in nature, except that they capture features specific to the Bank and the intervention. Most of them have been described elsewhere in the paper. For example, we use the policy variables identified by 
OED (described earlier) as dummy variables to control for the reform areas covered by the intervention. In this way, we can test whether specific reforms have, on average, met with more success than others (other relevant factors held constant). In particular, we can test whether the relatively poor performance of post-1990 interventions can be traced to the increased emphasis on particular reforms (privatization, re-capitalization, and supervision). In addition, to test whether FSALs are intrinsically distinct from other Bank interventions, we include an FSAL dummy. Finally, to test whether the comprehensiveness of an intervention affects its success, we include a continuous variable measuring the total number of reform areas covered. On an a priori basis, it is difficult to know whether comprehensive interventions are beneficial, or whether they overly complicate matters.

\section{(B). Results}

It should be emphasized at the outset that, given data limitations and the myriad factors that may affect financial sector performance in the years immediately subsequent to an intervention, one might not expect results to be as robust as recent ones from the growth literature; there, growth rates and some explanatory variables are averaged over long time periods. ${ }^{32}$ In addition, whereas most of those studies use samples of 50-100 countries, the sample here is much smaller (twenty-three observations). As noted above, because the IFS data run only through 1995 (for those countries whose data is complete),

32 Robust growth results, the focus of Levine and Renelt (1992), are also found in the institutional work of Knack and Keefer (1995). Knack and Keefer employ a number of the same variables as Levine and Renelt including average annual GDP per capita, average annual investment as a percentage of GDP, and average annual government consumption as a percentage of GDP, all measured over the period 1974-89. 
and because the benefits of these interventions appear to operate at least with a two to three year lag, the potential sample is cut dramatically. The small sample, in turn, makes the estimation quite sensitive to outliers. All that said, with minor corrections for outliers, the available data tell a consistent story across alternative model specifications. However, given so few degrees of freedom, the findings should, perhaps, be viewed with a healthy dose of skepticism. At the least, it should be emphasized that the modeling effort is a work in progress that will be refined as additional Bank projects in the financial sector mature.

As the summary statistics indicated, initial financial sector and macroeconomic conditions had implications for the success of an intervention. Model (1) essentially restates what we know from Table 2.3 - countries that had relatively under-developed financial systems and low inflation experienced the largest post-intervention improvements as measured by $\mathrm{M} 2 / \mathrm{GDP} .^{33}$ The limitations of the dependent variable should be emphasized. Ideally, one would like to measure the post-intervention health of the banking sector and, perhaps, the efficiency of capital allocation. While financial deepening may often coincide with improved health and efficiency, this need not always be the case. For example, in Tanzania there was much post-intervention financial deepening but, given the lack of serious institutional reform in the banking sector, it is quite unlikely that it

33 The result also holds for improvements in DBPC/GDP, although it is less robust across alternative specifications. In general, the DBPC/GDP results are more fragile than those for M2/GDP. The trade variables, in particular, perform poorly in the DBPC/GDP regressions. The overall fit of those regressions, moreover, fluctuates wildly across alternative specifications, and never approaches that of the M2/GDP regressions. This is somewhat troubling because, on an a priori basis, it is difficult to argue that the M2 data should be any more reliable than the DBPC data as both come from the same source. In any event, we present only the M2/GDP results. 
coincided with improved capital allocation or healthier banks (See discussion in Section IV).

The "group" explanatory variables in the regression tables are dummies that correspond to the country groups described in Table 2.3. The omitted category is group IV, countries that had relatively developed financial sectors and high inflation in the two years leading up to the intervention. The coefficient on group I, therefore, indicates that low-development, low-inflation countries experienced, on average, M2/GDP increases 7.5 points higher than did group IV countries. As is evident in the tables, the group I coefficient is statistically significant across a wide array of alternative specifications. For the intermediate countries (low-development, high inflation or high-development, lowinflation), the coefficients are positive, though less pronounced. When OED reform area dummy variables are included (Tables 3.2 and 3.3), the group II and III coefficients become positive in some specifications.

One might suspect that the results in Table 3.1 are sensitive to the way the country dummies were derived. To mimic these results using continuous variables, we replace the group dummies with an interaction variable that multiplies DBPC/GDP by inflation (Model 2). The coefficient on the interaction term enters negatively and significantly, as expected. When DBPC/GDP and inflation enter the model additively, DBPC/GDP provides most of the explanatory power; as predicted, it enters negatively and significantly across specifications (See Figure 1 for a visual display of these results). However, overall 
fit and robustness of results are best when the two variables enter multiplicatively, or when the two are used to construct the group dummies. When per capita GDP replaces DBPC/GDP in the specification (entering either on its own or as a part of the interaction term), the results are substantially similar to those presented. That is, its coefficient's sign is negative and significant in most specifications. ${ }^{34}$ The result provides support for the notion that, given the strong ties between the real and financial sectors emphasized by Gertler and Rose, conditional convergence is, to some extent, reflected in financial sector development.

It should be emphasized that both Models (1) and (2) are sensitive to the presence of outliers. In these models and all those that follow, M2/GDP improvements more than two standard deviations away from the sample mean were eliminated. In the first two specifications, this meant eliminating only the Nicaraguan observation from the analysis. When Nicaragua was included, the coefficients on most variables flipped and the adjusted R-squared of the regression sank to nearly zero. Specifications (3) through (20) extend the "two standard deviations" correction to all continuous variables used in the model. Thile many of the regression results are not overly sensitive to the outlier corrections on the continuous explanatory variables, they are slightly more robust when we apply the correction across the board. In most cases, moreover, a continuous variable value two standard deviations away from the sample mean is a strong indication that something was especially amiss at the time of the intervention, or that there were potentially serious

34 Calculations available from the author. 
measurement problems in the data. Similar regression results for the full sample -- except

Nicaragua -- appear in Appendix 9 (See Figure 2 for a visual display of the sample, and the key reforms covered by each intervention). ${ }^{35}$ The only important difference is that results regarding trade (IMP/GDP) no longer hold.

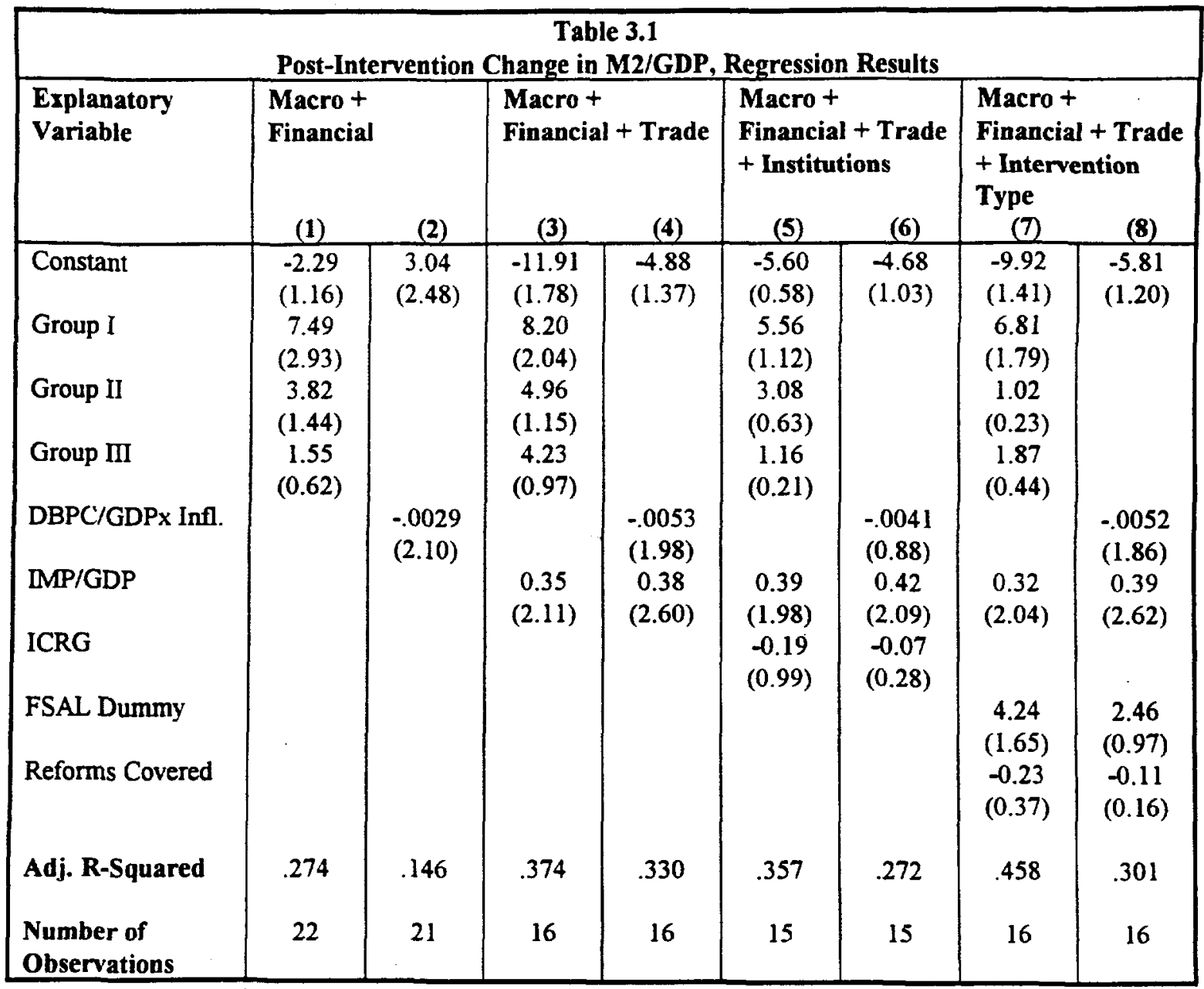

Note: $\mathbf{t}$-statistics in parentheses; group dummies defined in Table 2.2 .

35 Nicaragua experienced the largest post-loan increases in M2/GDP in the sample $(15.7 \%)$. As noted, the inclusion of the Nicaragua observation presents serious problems. This is likely due to measurement problems -- Nicaraguan inflation averaged over $1400 \%$ in the two years prior to the FSAL and over $30 \%$ in the two years subsequent to it. In addition, real GDP remained largely flat in the years immediately subsequent to the loan, and had still failed to reach its mid-80s levels three years after the loan. The increase in M2/GDP, therefore, was less reflective of true financial deepening than it would have been if GDP had been growing at a reasonable pace. 
Across all specifications in which it was included for the small sample, openness to trade as measured by IMP/GDP had a significant positive coefficient. On average, each 1 point increase in IMP/GDP implied a 4 point increase in M2/GDP three years after intervention. This would appear to confirm the notion that (1) open economies grow faster than others and (2) this growth is reflected in a larger financial sector. There are, however, some potential flies in the ointment. First, the results cannot be re-produced when EXP/GDP replaces IMP/GDP in the specification. In fact, although the coefficient for EXP/GDP never achieves significance, the sign is negative in some specifications. As Levine and Renelt point out, the link between growth and openness is robust across numerous indicators of trade, not just imports. For this sample, however, imports may be a more accurate indicator of openness to trade than exports. In the case of Venezuela, for example, their relatively high EXP/GDP figure (36.5\%) is probably more indicative of their vast oil reserves than of a general openness to trade. Their relatively low IMP/GDP figure (15.3\%) is, therefore, a better gauge of their inclination toward trade. By contrast, for the other countries in the sample, IMP/GDP exceeded EXP/GDP, which appears to be common across many developing countries.

A second problem with the trade results is that they cannot be extended to the full sample. ${ }^{36}$ That is, when all observations (except Nicaragua) are included in the regressions, the coefficient on MMP/GDP is generally positive, but small and not significantly different from zero. In addition, when the Summers-Heston measure of

36 See Appendix 9, models 29-35. 
openness (imports plus exports, divided by GDP) replaces IMP/GDP in the regressions, its coefficient is negative and significant across a number of specifications. Perhaps, similar to the results for initial deposit bank credit to the private sector (DBPC/GDP), those countries that are already relatively open to trade at the time of an intervention have less "room to grow" in terms of financial depth.

Another problem emphasized by Levine and Renelt is theoretical. A potential rationale for the IMP/GDP result is that international trade permits specialization which, in turn, improves resource allocation (and thus fosters growth). As noted, however, openness is highly correlated with investment as a percentage of GDP. When both openness and investment measures are included in growth regressions, therefore, openness loses substantial explanatory power. This suggests that openness contributes to growth through increased capital accumulation rather improved resource allocation. For our purposes, of course, it may not matter exactly how openness contributes to growth -- to the extent that it does, we simply expect a larger financial sector. However, both the lack of theoretical justification and the instability of the openness result with respect to other measures of openness are troubling. While openness may have implications for the success of an intervention, an ironclad result awaits both additional tests (either as additional interventions mature and data becomes available, or, perhaps, using alternative trade indicators) and theoretical advances. 
Regarding institutional explanatory variables, the results are mixed. Those that attempt to control for institutional quality in the recipient country have little explanatory power while those that control for institutional features related to the Bank -- the type of intervention, the nature of the reform -- are far more successful. Although the BERI and ICRG variables have substantial explanatory power in growth regressions, the same is not true here. ${ }^{37}$ There are a number of possible explanations. The most plausible is that DBPC/GDP and the indices are all measures of the security of property rights and thus are highly correlated. ${ }^{38}$ Clague et al, found a similar connection between contract intensive money -- the ratio of non-currency money to the total money supply -- and the security of property rights. ${ }^{39}$ Another explanation is that, for many of the countries in the sample, BERI data (and, to a lesser extent, ICRG data) were not available in the year of the intervention, which further limits an already small sample, and may make estimated coefficients somewhat less reliable. Yet another is that growth regressions typically include both industrialized and developing countries which often vary widely with respect to these indicators. Here, because we are restricted to Bank interventions (which tend to occur in countries with relatively low institutional capacity), we lose variation and,

37 This is true regardless of whether the BERI and ICRG variables enter the specification individually or as part of indices. The ICRG results appear in Table 3.1, models (5) and (6). Also, some parts of the indices (such as the BERI measure of expropriation risk) are, not surprisingly, highly co-linear with our initial conditions variables, which further muddles the specification. For example, in this small sample of developing countries, it appears that those that pose little expropriation risk to foreign investors also have relatively stable macroeconomic situations, at least as measured by inflation.

38 Indeed, the BERI index and initial DBPC/GDP are correlated at the .549 level. however the ICRG-DBPC/GDP correlation is only .142.

39 Clague et al. (1994), pp. 16-18. 
therefore, substantial explanatory power. ${ }^{40}$ A final potential explanation is that the BERI and ICRG variables do not sufficiently capture institutional characteristics that have implications for banking performance. ${ }^{41}$ Better indicators might focus on the autonomy and quality of the central bank or other proxies for the quality of bank supervision (e.g., supervisors' salaries). Unfortunately, no cross-country database exists that adequately captures salient institutional features of the banking sector. ${ }^{42}$ In short, that these broad institutional indices do not perform as expected may come as little surprise to many. The inconclusive results, moreover, speak to a need for more data on institutional features of the banking sector if the impact of interventions is to be well measured. ${ }^{43}$

The institutional variables that described the intervention provided substantially more explanatory power than did the BERI and ICRG indices. The coefficient for the number of reform areas covered in the intervention was negative and that for the FSAL

40 However, ICRG/BERI growth results are typically robust to sample selection (e.g., OECD vs. non-OECD countries). Of course, the regressions here employ only a small subset of non-OECD countries.

41 Of course, if the BERI and ICRG variables are robustly correlated with growth, and if the Gertler-Rose hypothesis is correct, there should be a positive partial correlation between these indicators and the size of the financial sector. That we don't find one suggests we have either measurement problems (as alluded to above) or, perhaps, that these indicators are not exogenous, and thus not truly correlated with growth.

42 OED is, however, striving to create one. Unfortunately, comparability of data across countries and a general lack of comprehensive data collection in many countries make this task especially arduous. Initial collection results are positive for some time series on banking indicators, but the series are not sufficiently complete for enough countries to permit their inclusion in the econometric analysis. On central bank independence, Cukierman and Webb (1993) also offer some indicators.

${ }_{43}$ Indeed, this data could also provide us with more direct ways to measure the success of an intervention rather than analyzing changes in M2/GDP. For example, data on loan classification or credit allocation by sector may tell us more about the success of an effort to reform directed credit or to privatize banks than would M2/GDP. 
dummy was positive (Table 3.1, Models 7,8 ). Only the FSAL dummy coefficient approached significance. However, changes in M2/GDP were best explained by the dummy variables corresponding to individual reform areas. In particular, relative to those interventions that did not attempt bank privatizations, those that did performed poorly. The privatization dummy coefficient was negative $(-3$ to $-4 \%)$, and significant. The full sample results, moreover, indicate that the most problematical privatizations were those that did not also focus on improved prudential regulations (See Appendix 9, models 30 and 31). Those that concentrated on both were generally a bit more successful than those interventions that did not focus on privatization (although the coefficient was not statistically different from zero). By contrast, those countries that privatized banks without paying attention to prudential regulations did far worse - the coefficient for countries in that group was negative, large (in absolute value), and approached significance. $^{44}$

Privatizations were, however, the only reform type from the ascending group that substantially under-performed other types of interventions. In fact, the bank recapitalization dummy coefficient indicates that interventions which included this type of reform out-performed others (Table 3.2, Models 13, 14). ${ }^{45}$ In absolute value this coefficient approaches that for the privatization dummy and attains the same marginal level of statistical significance. However, if one also includes a dummy indicating whether

44 In Argentina, where privatizations coincided with improvements in prudential regulations and supervision, banks' performance was substantially improved after privatization. See Clarke and Cull (1997).

45 See Appendix 9, models 32 and 33, for full sample results. 
prior financial sector interventions in that country had included re-capitalization, the original re-capitalization variable loses substantial explanatory power. In addition, the prior re-capitalization dummy has a negative coefficient, although it is not statistically significant from zero. Apparently, re-capitalizations increase moral hazard problems, especially when they do not entail high costs to bank owners and managers. After all, why protect capital when it is likely to replenished no matter how poorly one manages the bank?

To test whether re-capitalizations were more effective when coupled with reforms designed to alter bankers' incentives, we split the re-capitalization dummy into two variables -- a dummy for re-capitalizations that included prudential regulation reform, and another for those that did not. The results indicate that those projects that included both re-capitalization and prudential regulation reform were a bit more successful than those that involved re-capitalization without prudential reform (Appendix 8). ${ }^{46}$ Although the coefficient for projects that involved re-capitalization only was positive (near 2 ), it was not statistically significant from zero. These reforms were not, therefore, obviously more successful than those interventions that did not involve re-capitalization. The coefficient for projects that involved both re-capitalization and prudential regulation reform was

46 Again, see Appendix 9 for full sample results. Like the small sample results in Appendix 8, the coefficient for countries that re-capitalized and tried to improve prudential regulations was positive and significantly different from zero. However, the coefficient for those that only re-capitalized is also positive (and large), although its tstatistic is only 1.71 . In short, the full sample results are less clear-cut than the small sample results with respect to the beneficial effect of improved prudential regulations on re-capitalizations. 
larger (near 3), and approached or achieved significance across specifications. It appears that re-capitalizations were, on average, somewhat more successful than other types of projects -- provided some attention was paid to the incentives faced by bankers in the form of prudential regulations. ${ }^{47}$

The bank supervision dummy variable was also positive, although the coefficient did not approach significance and was smaller in absolute value than either the privatization or the re-capitalization variables. ${ }^{48}$ On average, interventions that included bank supervision reform performed no better or worse than those that did not. ${ }^{49}$ We again split the re-capitalization dummy into two variables, one for those that included supervision reform, another for those that did not. The results were somewhat similar to those for prudential regulation reform. That is, relative to interventions that did not involve bank re-capitalization, those that addressed both re-capitalization and supervision were, on average, more successful. Those that addressed only re-capitalization were not. ${ }^{50}$ Again, it appears that, given sufficient attention to bank supervision and prudential regulations, re-capitalizations can be at least as successful as other types of financial sector operations (See Figure 3 for a visual depiction of these results, and those for privatization).

47 Again, one would also like to know if the health and allocative efficiency of the financial sector improved after re-capitalizations that also focused on improved banking regulations.

48 See Appendix 9, models 34 and 35, for full sample results.

49 Perhaps little reform was actually accomplished, or a longer time lag is required before supervision reform bears fruit.

so The result is somewhat surprising because, as alluded to above, improving bank supervision is typically an arduous process that takes years to pay off. 
Table 3.2

Post-Intervention Change in M2/GDP, Regression Results

Reforms in Ascending Group

\begin{tabular}{|c|c|c|c|c|c|c|c|c|}
\hline \multirow[t]{2}{*}{$\begin{array}{l}\text { Explanatory } \\
\text { Variable }\end{array}$} & \multicolumn{2}{|c|}{$\begin{array}{l}\text { Macro + } \\
\text { Financial + } \\
\text { Ascending }\end{array}$} & \multicolumn{2}{|c|}{$\begin{array}{l}\text { Macro + } \\
\text { Financial + Trade } \\
\text { + Privatization }\end{array}$} & \multicolumn{2}{|c|}{$\begin{array}{l}\text { Macro + } \\
\text { Financial + Trade } \\
+ \text { Re- } \\
\text { Capitalization }\end{array}$} & \multicolumn{2}{|c|}{$\begin{array}{l}\text { Macro + } \\
\text { Financial + Trade } \\
\text { + Supervision }\end{array}$} \\
\hline & (9) & $(10)$ & (11) & (12) & (13) & (14) & (15) & (16) \\
\hline Constant & $\begin{array}{r}-11.00 \\
(1.66)\end{array}$ & -5.22 & $\begin{array}{r}-14.70 \\
(2.34)\end{array}$ & $\begin{array}{l}4.52 \\
(1.35)\end{array}$ & $\begin{array}{l}-9.76 \\
(1.57)\end{array}$ & $\begin{array}{c}-6.74 \\
(1.86)\end{array}$ & $\begin{array}{l}-13.80 \\
(2.18)\end{array}$ & $\begin{array}{l}-5.27 \\
(1.39)\end{array}$ \\
\hline Group 1 & $\begin{array}{c}7.38 \\
(1.85)\end{array}$ & & $\begin{array}{c}8.94 \\
(2.43)\end{array}$ & & $\begin{array}{c}5.51 \\
(1.40)\end{array}$ & & $\begin{array}{c}9.37 \\
(2.47)\end{array}$ & \\
\hline Group 2 & $\begin{array}{l}2.98 \\
(0.66)\end{array}$ & & $\begin{array}{c}8.57 \\
(1.95)\end{array}$ & & $\begin{array}{c}2.22 \\
(0.53)\end{array}$ & & $\begin{array}{l}5.63 \\
(1.40)\end{array}$ & \\
\hline Group 3 & $\begin{array}{c}2.44 \\
(0.54)\end{array}$ & & $\begin{array}{c}6.75 \\
(1.60)\end{array}$ & & $\begin{array}{c}1.25 \\
(0.29)\end{array}$ & & $\begin{array}{c}4.79 \\
(1.17)\end{array}$ & \\
\hline DBPC/GDPx Infl. & & $\begin{array}{l}-.0051 \\
(1.83)\end{array}$ & & $\begin{array}{l}-.0045 \\
(1.79)\end{array}$ & & $\begin{array}{l}-.0040 \\
(1.48)\end{array}$ & & $\begin{array}{l}-.0051 \\
(1.82)\end{array}$ \\
\hline IMP/GDP & $\begin{array}{c}0.29 \\
(1.67)\end{array}$ & $\begin{array}{c}0.37 \\
(2.44)\end{array}$ & $\begin{array}{c}0.43 \\
(2.74)\end{array}$ & $\begin{array}{c}0.39 \\
(2.83)\end{array}$ & $\begin{array}{l}0.291 \\
(1.86)\end{array}$ & $\begin{array}{c}0.36 \\
(2.60)\end{array}$ & $\begin{array}{c}0.33 \\
(2.09)\end{array}$ & $\begin{array}{c}0.37 \\
(2.42)\end{array}$ \\
\hline $\begin{array}{l}\text { Ascending } \\
\text { Privatization }\end{array}$ & $\begin{array}{c}3.99 \\
(1.19)\end{array}$ & $\begin{array}{c}0.83 \\
(0.25)\end{array}$ & $\begin{array}{c}-4.18 \\
(1.82)\end{array}$ & $\begin{array}{l}-3.27 \\
(1.67)\end{array}$ & & & & \\
\hline Re-Capitalization & & & & & $\begin{array}{c}3.20 \\
(1.80)\end{array}$ & $\begin{array}{l}2.80 \\
(1.51)\end{array}$ & & \\
\hline Supervision & & & & & & & $\begin{array}{c}2.85 \\
(1.66)\end{array}$ & $\begin{array}{c}0.90 \\
(0.46)\end{array}$ \\
\hline Adj. R-Squared & .398 & .278 & .482 & .411 & .480 & .391 & .460 & .287 \\
\hline $\begin{array}{l}\text { Number of } \\
\text { Observations }\end{array}$ & 16 & 16 & 16 & 16 & 16 & 16 & 16 & 16 \\
\hline
\end{tabular}

Note: $t$-statistics in parentheses; group dummies defined in Table 2.2.

Among the three descending reforms (interest rate distortions, non-bank financial

regulations, and prudential regulations), only prudential regulation reforms appear to have been substantially more successful than other types of reforms. Relative to other interventions, those that tackled interest rate distortions were somewhat better able to boost M2/GDP, but the disparity was not statistically significant. Similarly, those interventions that dealt with non-bank financial regulations performed somewhat better than those that did not, although the result approached significance in Model (21) but not 
in (22). The result's instability suggests that these interventions did not perform substantially better than those that did not address non-bank regulations. Among all reform areas, however, the Bank's greatest relative successes have occurred with respect to prudential regulation reform. The relatively large positive coefficient on the prudential dummy (4-5\%) and its statistical significance across specifications (Table 3.3, Models 23 and 24), suggest that development of the financial sector has been linked with World Bank intervention in the regulatory framework that governs banks in a recipient country. ${ }^{51}$

Bank efforts to strengthen financial institutions do, therefore, have a positive impact on project outcomes. As many of these institution building efforts are less "visible" than other reforms (bank privatizations, re-capitalizations, interest rate de-regulation), this may be an important area for Bank involvement when political or macroeconomic conditions do not favor bold steps.

31 The full sample results (Appendix 9, model 29) are less pronounced with respect to prudential regulations. However, the importance of prudential regulations is clear when that variable is interacted with the re-capitalization and privatization variables as discussed above (models 31 and 33). 


\begin{tabular}{|c|c|c|c|c|c|c|c|c|}
\hline \multicolumn{9}{|c|}{$\begin{array}{c}\text { Table 3.3 } \\
\begin{array}{c}\text { Post-Intervention Change in M2/GDP, Regression Results } \\
\text { Reforms in Descending Group }\end{array} \\
\end{array}$} \\
\hline \multirow[t]{2}{*}{$\begin{array}{l}\text { Explanatory } \\
\text { Variable }\end{array}$} & \multicolumn{2}{|c|}{$\begin{array}{l}\text { Macro + } \\
\text { Financial + } \\
\text { Descending }\end{array}$} & \multicolumn{2}{|c|}{$\begin{array}{l}\text { Macro + } \\
\text { Financial + Trade } \\
+ \text { Interest Rate } \\
\text { Distortion }\end{array}$} & \multicolumn{2}{|c|}{$\begin{array}{l}\text { Macro + } \\
\text { Financial + Trade } \\
+ \text { Non-Bank } \\
\text { Financial } \\
\text { Regulation }\end{array}$} & \multicolumn{2}{|c|}{$\begin{array}{l}\text { Macro+ } \\
\text { Financial + Trade } \\
\text { + Prudential } \\
\text { Regulations }\end{array}$} \\
\hline & (17) & (18) & (19) & $(20)$ & (21) & (22) & (23) & (24) \\
\hline Constant & $\begin{array}{l}-12.90 \\
(1.96)\end{array}$ & $\begin{array}{l}-7.52 \\
(1.83)\end{array}$ & $\begin{array}{l}-12.95 \\
(1.98)\end{array}$ & $\begin{array}{l}-6.65 \\
(1.54)\end{array}$ & $\begin{array}{l}-13.60 \\
(1.83)\end{array}$ & $\begin{array}{l}-4.88 \\
(1.86)\end{array}$ & $\begin{array}{l}-19.73 \\
(2.99)\end{array}$ & $\begin{array}{l}-8.34 \\
(2.16)\end{array}$ \\
\hline Group 1 & $\begin{array}{c}6.77 \\
(1.66)\end{array}$ & & $\begin{array}{c}7.17 \\
(1.81)\end{array}$ & & $\begin{array}{c}9.51 \\
(2.03)\end{array}$ & & $\begin{array}{l}9.81 \\
(2.83)\end{array}$ & \\
\hline Group 2 & $\begin{array}{l}3.09 \\
(0.69)\end{array}$ & & $\begin{array}{c}2.66 \\
(0.59)\end{array}$ & & $\begin{array}{c}5.89 \\
(1.25)\end{array}$ & & $\begin{array}{l}5.86 \\
(1.60)\end{array}$ & \\
\hline Group 3 & $\begin{array}{l}3.20 \\
(0.74)\end{array}$ & & $\begin{array}{l}2.91 \\
(0.67)\end{array}$ & & $\begin{array}{c}5.34 \\
(1.10)\end{array}$ & & $\begin{array}{l}7.05 \\
(1.81)\end{array}$ & \\
\hline DBPC/GDPx Infl. & & $\begin{array}{l}-.0043 \\
(1.59)\end{array}$ & & $\begin{array}{l}-.0049 \\
(1.77)\end{array}$ & & $\begin{array}{l}-.0053 \\
(1.83)\end{array}$ & & $\begin{array}{l}-.0050 \\
(2.03)\end{array}$ \\
\hline IMP/GDP & $\begin{array}{c}0.34 \\
(2.11)\end{array}$ & $\begin{array}{c}0.37 \\
(2.60)\end{array}$ & $\begin{array}{c}0.38 \\
(2.35)\end{array}$ & $\begin{array}{c}0.41 \\
(2.67)\end{array}$ & $\begin{array}{c}0.40 \\
(2.11)\end{array}$ & $\begin{array}{c}0.38 \\
(2.33)\end{array}$ & $\begin{array}{c}0.44 \\
(3.02)\end{array}$ & $\begin{array}{c}0.39 \\
(2.90)\end{array}$ \\
\hline Descending & $\begin{array}{c}4.00 \\
(1.26)\end{array}$ & $\begin{array}{c}3.91 \\
(1.23)\end{array}$ & & & & & & \\
\hline Interest Rate Dist. & & & $\begin{array}{c}2.61 \\
(1.31)\end{array}$ & $\begin{array}{c}1.50 \\
(0.76)\end{array}$ & & & & \\
\hline $\begin{array}{l}\text { Non-Bank Fin. } \\
\text { Reg. }\end{array}$ & & & & & $\begin{array}{c}3.20 \\
(1.80)\end{array}$ & $\begin{array}{l}.0089 \\
(.004)\end{array}$ & & \\
\hline Prudential Reg. & & & & & & & $\begin{array}{c}4.74 \\
(2.31)\end{array}$ & $\begin{array}{c}3.72 \\
(1.75)\end{array}$ \\
\hline Adj. R-Squared & .405 & .356 & .412 & .411 & .480 & .275 & .552 & .422 \\
\hline $\begin{array}{l}\text { Number of } \\
\text { Observations }\end{array}$ & 16 & 16 & 16 & 16 & 16 & 16 & 16 & 16 \\
\hline
\end{tabular}

Note: $t$-statistics in parentheses; group dummies defined in Table 2.2.

In many ways, the regression results merely help formalize notions suggested by the summary statistics of the first two sections. For example, a relatively under-developed financial sector and macroeconomic stability (as reflected in a low inflation rate) are both associated with growth in M2/GDP. Even after controlling for those factors, however, there are systematic differences in the performance of interventions. In particular, relatively open economies appear to benefit more from financial sector interventions than 
do others. While that result corresponds nicely with others from the growth literature, it should be re-emphasized that it is not robust across alternative trade indicators. ${ }^{52}$ Finally, and most importantly, after controlling for inflation, trade, and initial financial sector development, the nature of the intervention explains substantial variation in outcomes. In some respects, therefore, the changing nature of financial sector reforms described in Section I appears to have had a negative effect on performance, at least in a relative sense. Interventions focused on privatization (a point of emphasis in later projects), have performed worse than others (if only in the three years subsequent to the loan). In addition, FSALs appear to have out-performed other interventions; and those interventions focused on prudential regulations have performed better than others. The results also have been encouraging for re-capitalizations, especially those that have also focused on prudential regulation reform and/or bank supervision. Intriguing though they may be, these are, of course, only partial correlations derived from a very limited data set. As additional data becomes available, the correlations may become more robust. Reliable or not, however, correlations do not necessarily imply causation. Understanding whether and why open economies tend to outperform others, or why FSALs tended to out-perform non-FSALs (at least this for this sample), or why privatizations have gone relatively poorly, requires details that our regressions cannot easily provide. In an effort to uncover

52 Nor is it robust to inclusion of those observations for which DBPC/GDP, inflation, or IMP/GDP were more than two standard deviations away from the sample mean. While some of these observations are likely subject to measurement error - especially those for countries that experienced especially high inflation -- it is troublesome that the IMP/GDP result does not hold up for all twenty-two potential observations in the sample. By contrast, the results for initial conditions and the relative effectiveness of individual reforms hold up across all observations (except Nicaragua). Again, results for the twentytwo observation sample appear in Appendix 9. 
some of those details, we use the regression results to help select specific cases which we analyze in the next section.

\section{Case Studies of Financial Sector Interventions}

\section{(A). Philippines}

Countries with financial sectors that were substantially similar at the time of the intervention experienced very different improvements in M2/GDP. For example, deposit bank credit as a percentage of GDP was roughly $17 \%$ in both the Philippines and Venezuela at the time of the intervention. The interventions occurred at roughly the same time (Philippines 1989, Venezuela 1990); both were relatively comprehensive FSALs covering six reform areas. Three years after the intervention, however, M2/GDP had increased by 5.61 points in the Philippines while it had declined by 4.14 points in Venezuela. What explains the wide disparity? No doubt, a large part of the Philippine success can be traced to favorable initial conditions -- the banking sector was relatively under-developed, average inflation in the two years prior to intervention was relatively low $(10.47 \%)$, and, relative to many other developing countries, the Philippines was open to international trade (MMP/GDP was 26.3\%). Indeed, these are the ideal initial conditions for reform as identified by the models in the previous section. It is little surprise, therefore, that the model predicted a 4.77 point increase in M2/GDP. ${ }^{53}$

53 The predictions in this section are derived from model (24). 
Yet, these favorable initial conditions did not arrive out of thin air. Some were the product of comprehensive economic reform that began in the early 1980 s including exchange rate flexibility and removal of agricultural price distortions. ${ }^{54}$ Substantial trade liberalization was achieved under a $1986 \mathrm{IMF}$ agreement and, to further improve the real sector, the Bank undertook an Industrial Restructuring Project Loan just subsequent to the FSAL. ${ }^{\text {ss }}$ In addition, although the results were yet to be reflected in higher M2/GDP, substantial reform had been undertaken in the financial sector: in the early ' 80 s, interest rates had been de-regulated, bank capital reserve requirements had been increased, and universal banking was introduced. ${ }^{56}$ In $1986-7$, the two largest government financial institutions were restructured with Bank support and, in subsequent years, treasury bill auctions began, and preliminary steps were taken to improve supervision of securities markets institutions. ${ }^{57}$ Although it is difficult to ascertain precisely which of these reforms were necessary for the success of the FSAL, it is also difficult to quibble with the Bank's assessment that policy lending operations had "led to an environment conducive to concentrate on the reforms of the financial system." 58

Despite the progress that had been made, a 1987 study identified four remaining major problems in the financial sector: bank supervision, protection of depositors,

54 World Bank, "Philippines FSAL: Performance Audit Report (PAR)," June 28, 1996, pp. 9, 17.

ss World Bank, "Philippines FSAL: Project Completion Report (PCR)," June 16, 1995, p. 6.

s6 Ibid., pp. 5-6.

57 PAR, p. 9.

58 PCR, p. 7. 
lowering intermediation costs, and delivery of long-term credit. On supervision, the loan specified that the Central Banking Act be amended to include guidelines for emergency loans to banks in distress, transparent criteria for issuing cease and desist orders, new rules for lending to bank insiders, and liability insurance for central bank staff. ${ }^{59}$ With respect to deposit insurance, the Philippines Deposit Insurance Corporation (PDIC) increased its fee structure and increased its capital by three billion pesos (US\$ 115 million). Intermediation costs remained high despite reduced taxes on intermediaries, fewer restrictions on foreign bank entry, and the elimination of branching restrictions. ${ }^{60}$ It is unlikely, however, that these developments had substantial impact on the increase in $\mathrm{M} 2$ three years after the intervention -- most of PDIC's capital increase was scheduled for 1991-2 and arrived late, ${ }^{61}$ legislation liberalizing foreign bank entry was passed in 1994, and, although 148 new branches were allowed to be established in 1990-91, it is unclear how many were actually in operation in those years. ${ }^{62}$ Finally, with respect to delivery of long-term credit, directed credit schemes were transferred from government ministries to the Development Bank of Philippines (DBP), which was then scheduled to be privatized four years hence. Once again, it seems unlikely that this gradual change was responsible for any of the increase in M2 three years after the FSAL, although it may have contributed to subsequent increases.

59. PAR, p. 10.

60 PAR, p. 10. PCR, p. 22. World Bank, "Philippines FSAL: President's Report (PR)," April 6, 1989, p. 24.

61 PCR, p. 10, 32.

62 Of course, the mere threat of entry may change the behavior of incumbents. I assume, therefore, that the disciplinary effect of the announced entrants was not primarily responsible for the post-FSAL financial deepening. 
Although some of the required legislation was difficult to pass, and thus made cancellation of the second tranche of the loan a possibility ${ }^{63}$ the Bank viewed the Philippine FSAL a success owing, in part, to the high priority and ownership of the program by the Government. ${ }^{64}$ That success, moreover, was achieved despite exogenous shocks -- an '89 coup attempt, a '90 earthquake, and a volcano eruption in '91. Interestingly, the Bank pointed to the increase in financial deepening (as measured by M2/GDP) as an indication that the FSAL had been a success. ${ }^{65}$ As noted, however, it appears quite unlikely that a FSAL focused exclusively on institutional developments in the financial sector that all took a relatively long time to implement was responsible for this improvement. More likely candidates were the reforms undertaken during the ' 80 s, especially those that contributed to macro-stabilization and openness to trade (if our models are to be believed). ${ }^{66}$ The Bank drew the following from the Philippine experience:

A FSAL focusing on institutional strengthening has a better chance to succeed when the economy has reached a significant level of trade and financial sector liberalization. ${ }^{67}$

In this instance, it appears probable that the Bank erroneously attributed to the FSAL financial sector deepening that was a natural by-product of trade liberalization, macrostability, and more basic financial sector reforms. This is not to argue that this narrowly-

\footnotetext{
63 Ibid, p. 10.

$64 \quad$ Ibid., p. 16.

65 PAR, p. 10.

66 The Bank was also quick to note that macro-economic stability was necessary for the success of financial reform. PAR, p. 27.

$67 \quad$ Ibid., p. 27.
} 
tailored FSAL didn't have its merits, but rather that any positive effects were likely to be felt later on, and were probably unlikely to be reflected in dramatic jumps in M2.

\section{(B). Venezuela}

The case of Venezuela further underscores the primacy of reforms that focus on trade liberalization and macro-stability. As noted above, at the time of its intervention, Venezuela's financial sector was at a stage of development similar to that of the Philippines. Venezuela, however, had not undergone reform sufficient to instill macro stability nor openness to trade -- in the two years prior to intervention inflation averaged $62.7 \%$; in the intervention year, imports were only $15.3 \%$ of GDP. Largely due to these two factors, the model predicted that Venezuela's M2/ GDP would undergo a 3.84 point contraction in the wake of the intervention. In fact, a 4.14 point contraction occurred.

These were not, however, the only two respects in which the two countries differed, as the Philippines was also somewhat further along the road to sustainable financial sector reform in some key areas. Although the Venezuelan FSAL was a part of a comprehensive reform program, and although progress had been made on a number of issues including exchange rate unification, deficit reduction, reduced protectionism, interest rate liberalization, and the transformation of indirect subsidies into focused social programs, a bit more had probably been accomplished in the Philippine case. ${ }^{68}$ In the President's Report (PR) that accompanied the Venezuelan FSAL, the Bank identified fundamental financial sector reforms yet to be achieved: further interest rate liberalization,

68 Venezuela PCR, March 14, 1995, p. 3. 
the elimination of agricultural credit requirements for commercial banks, the privatization of a number of public banks, less Central Bank involvement in the private credit market, the strengthening of weak financial intermediaries through fewer operational restrictions, and, finally, the strengthening of intermediary competition through additional entry and the aforementioned privatizations. ${ }^{69}$ Much of the list looks similar to the remaining problems in the Philippines at the time of the intervention -- directed credit, a clearer role for the Central Bank, too many restrictions on intermediaries, and little intermediary competition. The important differences in the Venezuelan case were the inclusion of further interest rate liberalization and the privatization of some public banks. In the Philippine case, interest rates were liberalized prior to the FSAL in an economic environment substantially less inflationary than Venezuela's, and major public financial institutions had already been substantially re-structured with an eye toward their eventual privatization. ${ }^{70}$

These differences proved important. In its Performance Audit Report, the Bank rated the Venezuela project unsatisfactory, its sustainability uncertain, and its institutional development modest. ${ }^{71}$ The key reason was that interest rates were liberalized in an unstable macro-environment, which led to wide rate swings and, eventually, disintermediation. ${ }^{72}$ Citing the Bank's "Report of the Task Force on Financial Sector

\footnotetext{
69 Venezuela PR, May 21, 1990, p. 23. Venezuela PAR, June 30, 1995, p. 21.

70 It is striking that neither improved supervision nor strengthened prudential regulations were mentioned as important remaining problems in Venezuela, a country where financial sector reform was in its infancy at the time of the FSAL.

71 PAR, pp. 12-13.

72 In addition, at time of the liberalization, many banks were probably insolvent. With no improvements in supervision, these bankers were unlikely to exhibit the prudent behavior that fosters financial deepening.
} 
Operations," the PAR indicated that these effects could have been avoided had the Bank's best practice been followed:

We must be mindful that the liberalization of financial markets, even more than in other sectors, can be dangerously destabilizing, unless the preconditions for efficient, competitive market operation are in place. ${ }^{73}$

The PAR concluded that macroeconomic stability was among the more obvious of these preconditions. ${ }^{74}$ To have privatized public banks during this unstable period probably compounded Venezuela's problems: if the regressions are any guide, even after controlling for macroeconomic instability, the Bank has, on average, had less luck with bank privatizations than other reforms. Interestingly, the PAR gave the Government passing marks for privatizing four of the nine commercial banks that it owned and liquidating an agricultural credit institution. However, the PAR also noted that in midJanuary 1994, the second largest bank in the country stopped operations and seven other banks became unable to continue operating without large cash infusions from the Central Bank. $^{75}$ Rather than assume a more forceful role, the Central Bank continued to provide liquidity to these seven for months until they, too, proved insolvent (at which point the Government took them over). While it is unclear from the PAR whether any of the newly privatized banks were among the seven insolvencies, it nevertheless may have been unwise, in retrospect, to have privatized banks in such a turbulent environment.

73 World Bank, R89-163, August 1, 1989. The Bank's Development Economics and Chief Economist Office (DEC) had also criticized this loan ex ante, arguing that interest rate de-regulation with insolvent institutions subject to poor supervision and insufficient prudential regulations was a bad recipe.

The PAR does, however, point out that it was not until February, 1992 that the Bank issued new Operational directives that emphasized caution in financial liberalization in the face of macroeconomic instability or sharp changes in relative prices. PAR, p. 30. 75 PAR, p. 20. 
It is interesting to note that, like the Philippines, Venezuela underwent a number of exogenous shocks just subsequent to the FSAL -- oil revenues plummeted to their preGulf War levels in 1991, and there was an attempted coup and a collapse of the Caracas Stock Exchange in 1992. Although these shocks (especially the collapse of the stock exchange) were, perhaps, more intimately related to the banking sector than those in the Philippines, Philippine financial sector development continued unabated. It would not, therefore, appear to be appropriate to ascribe the difference in the performance between the two cases largely to exogenous shocks. Instead, it appears that the root cause of the Venezuelan debacle stemmed from the sequencing of reforms. ${ }^{76}$ As the PAR emphasized, very little good can come from interest rate liberalization in an unstable macroeconomic environment, especially when banks are insolvent, supervision lax, and prudential regulations inadequate. ${ }^{77}$ Releasing the third tranche of the loan when macroeconomic conditions had not substantially improved, moreover, may also have been unwise. ${ }^{78}$ As the regression models and the Philippine case indicate, the earliest reform efforts may have been best concentrated on achieving macro-stability. Similarly, the Venezuelan Government may have been better served by opening its markets a bit more to international trade in the earliest stages of reform. While the bank privatizations were not

\footnotetext{
76 It should also be noted that institutional strengthening (especially with regard to bank supervision) occurred at a slower pace than either the Bank or the Venezuelan Government envisioned due to the Venezuelan Congress's rejection of a technical assistance component that accompanied the FSAL. It is unlikely, however, that the world's finest bank supervisors could have ameliorated the problems arising from liberalizing interest rates in an unstable macroeconomic environment. PAR, pp. 22-23. 77 PAR, pp. 11-12, 14, 23.

78 The PAR makes the same point, p. 14.
} 
at the root of these problems, it is obvious that they did little to help resolve them. No doubt, it would have been much easier for the privatized banks had they emerged to a stable macro environment and a healthier real sector which was increasingly predicated on international trade.

Based on the foregoing, it is difficult to conclude whether the institutional strengthening components of FSALs contributed to financial deepening in and of themselves. In the Philippine case, for example, one could conclude that the FSAL was a lagging indicator, a reflection that prior reforms had crystallized to a point were the Bank felt it appropriate to devote an entire project to financial sector adjustment. The postFSAL increase in $\mathrm{M} 2$, therefore, was more appropriately attributed to prior reforms, especially those that spurred openness or macro-stability. In short, the institutional strengthening component of this particular FSAL may have had little independent impact on development of the Philippine financial sector. ${ }^{79}$ The Venezuelan case further underscores the primacy of reforms based on trade liberalization and macroeconomic stability in deepening the financial sector. Although one institutional feature of that FSAL -- namely, bank privatizations -- may have contributed negatively to the project's outcome, the root causes of the failure appear not to have been institutional. In an effort to highlight the extent to which institutional components of FSALs have exerted an independent force on financial deepening, we turn to the cases of Pakistan and Tanzania.

79 However, some institutional strengthening may have been so crucial that it had to occur prior to the FSAL. The loan, therefore, may have been an ex post reward for the institutional reform that had already taken place. Indeed, in the three years prior to the FSAL, M2/GDP went from $26.7 \%$ to $32.4 \%$. 


\section{(C). Pakistan}

From the perspective of the models in the previous section, Pakistan's initial conditions were less than promising. Although inflation was moderate in the two years prior to the FSAL (averaging $8.4 \%$ ), the private banking sector was better developed than in most of the countries in the sample (DBPC/GDP was 25.4\%). The interaction term used in many of the models (DBPC/GDP * inflation) was, therefore, among the larger ones in the sample. ${ }^{80}$ In addition, Pakistan's openness to international trade was below the sample average (IMP/GDP was 19.0\%). Largely because of these factors, the model predicted only a modest increase in M2/GDP ( 1.8 points) in the wake of the FSAL. The Bank also recognized that initial conditions had an adverse effect on the loan noting that, "without significant improvements on the stabilization front, the benefits of the reforms

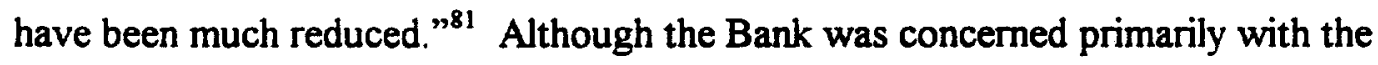
negative effects of inflation and the large fiscal deficit, a lack of trade openness and an already substantially developed (if highly imperfect) private banking system also probably exacted a toll on the rate of financial deepening.

According to the Bank's Project Completion Report, the saving grace of the Pakistan FSAL was the success of a number of reforms aimed at strengthening financial institutions. Prior to the FSAL, a number of foreign private banks received licenses, the

80 Its large DBPC/GDP figure, moreover, moved Pakistan into Group III (high financial development, low inflation countries). The models and summary statistics indicated that Group III countries were among the worst performers in terms of postintervention financial deepening.

81 Pakistan: PCR, March 16, 1995, p. iii. 
capital base of nationalized commercial banks (NCB) was strengthened, directed credit was limited, and interest rates were largely liberalized. ${ }^{82}$ In 1988 , the Government of Pakistan formulated a Financial Sector Adjustment Program to tackle remaining problems. That program highlighted six main areas for future reform: (1) macroeconomic stabilization to be achieved by reducing the fiscal deficit and controlling monetary aggregates, (2) more efficient issuance of Government debt, (3) more market-based credit allocation (through raising concessional rates of interest and limiting directed credit schemes), (4) further re-capitalization and restructure of nationalized commercial banks, (5) improvement in prudential regulations and supervision governing all financial institutions, and (6) promoting the entry of additional private banks. While this list may look eerily similar to that for both the Philippines and Venezuela, the PCR suggests that Pakistan was somewhat more successful in implementing the reforms. Of course, PCRs are sometimes more optimistic than Bank audits (PARs), and the PAR for Pakistan is yet to be completed. In any event, the PCR indicates that the Government introduced auctions for its debt, converted much of that debt into longer terms, kept directed credit within limits agreed to by the Bank, began supervising non-bank financial intermediaries, and established a credit bureau and banking courts. It also conducted audits of NCBs, saw to it that they achieved the requisite capital adequacy ratio, and then scrapped its plan to restructure them in favor of privatization, which it began doing in $1991 .^{83}$

\footnotetext{
82 PCR, pp. 2-3.

83 PCR, pp. 6-11. As noted, however, the pace of bank privatization subsequently proved disappointing.
} 
Given Pakistan's apparent commitment to institutional reform, it is no surprise that the Bank considered that FSAL a success, at least at the PCR stage. The project was rated satisfactory, its outcomes sustainable, and the resulting institutional development substantial. $^{84}$ The PCR, moreover, viewed these positive institutional developments as "remarkable in light of the disappointing macroeconomic results," Pakistani Government had taken reform further than the FSAL had envisaged with respect to commercial bank restructuring and competition from new private financial institutions. ${ }^{86}$ Although the Bank claimed little financial deepening after the FSAL, the IFS data did indicate a moderate increase in M2/GDP ( $+2.5 \%$, three years after the loan). At the least, the disintermediation of the pre-FSAL period appeared to have been reversed. ${ }^{87}$ In short, Pakistan's experience suggests that minor progress can be made towards financial deepening in environments where the initial conditions are found wanting (as viewed by both the Bank and the models of the previous section). Again, however, absent a full audit, it remains a bit unclear whether these institutional reforms are sustainable. If not, the meager financial deepening that was achieved may be reversed.

\section{(D). Tanzania}

On the other hand, Tanzania makes it clear that, in countries with relatively favorable initial conditions, post-FSAL financial deepening may occur despite the failure of the institutional reform program. In two respects, Tanzania conformed to the model's

\begin{tabular}{ll}
\hline 84 & PCR, Cover memo. \\
85 & PCR, p. 12. \\
86 & PCR, p. 5. \\
87 & PCR, p. iv.
\end{tabular}


ideal initial conditions for substantial post-intervention deepening -- its openness to trade (IMP/GDP was 36.3\%) and its under-developed financial sector (DBPC/GDP stood at 16.3\%). In another respect, Tanzania was less than ideal: its thirty percent inflation rate implied an instability that should have discouraged financial intermediation. Because subsequent inflation proved to be both lower and predictable (in the $20-25 \%$ range), however, it did little to forestall financial deepening. Largely on the basis of its trade openness and under-developed banking sector, the model predicted a seven point increase in M2/GDP. The actual figure proved to be almost nine, although, as we discuss below, the particular brand of deepening was not necessarily extolled by the Bank.

As in the other cases, Tanzania's FSAL was part of a larger reform effort, and its focus was developed from a financial sector development report undertaken by the Government. In 1986, the Government introduced its Economic Recovery Program (ERP) to improve macroeconomic management, tackle underlying structural weaknesses, and encourage a more vibrant private sector. Specific ERP reforms included a substantial depreciation of the overvalued exchange rate, trade liberalization, the removal of most price controls, and the easing of restrictions on the marketing of food crops. The reform effort helped spur economic growth -- the average annual growth rate in GDP was 4\% from 1986-91. ${ }^{88}$ Against this backdrop of successful reform, a Presidential Banking Commission Report was undertaken to chart a course for institutional strengthening in the financial sector. That report identified a four-pronged approach to financial reform

Tanzania: PCR, August 10, 1995, pp. 1-2. 
including: (1) creating a stable macroeconomic framework, including indirect methods of monetary control, (2) financial infrastructure strengthening including revision of banking and associated legislation, introduction of banking supervision functions at the Bank of Tanzania, and a review of the accounting and auditing framework, (3) creating a more competitive banking environment through increased private participation, and (4) the restructuring and re-capitalization of existing banks including the creation of a trust for the collection and liquidation of non-performing assets in the banking system.

Again we see the usual litany -- macro stabilization, prudential regulations and supervision, increased competition through entry, restructuring and re-capitalization. Unlike Pakistan, however, the results for Tanzania in these areas were either mixed or disappointing. Indirect monetary control was achieved in part through the introduction of treasury bill auctions, although an expansive monetary policy contributed to inflation that kept interest rates high (both nominal and real). Bank supervision may have improved due to new prudential regulations, but Bank of Tanzania staff lacked the skills necessary to exercise new enforcement powers. Two new banks began operations in 1993, although the restructuring plan for the National Bank of Commerce appeared largely ineffective. Finally, although government owned financial institutions were re-capitalized and significant portions of their non-performing assets were transferred to the liquidation trust, the banks were still insolvent and incurring substantial losses in the years after the intervention. ${ }^{89}$ It was little wonder, therefore, that the Bank rated the project

89 PCR, pp. 10-11. 
unsatisfactory, its institutional development negligible, and its meager achievements unsustainable.

Surprisingly, from the perspective of financial deepening, the years just subsequent to the FSAL were less disappointing than the Bank's assessment might lead one to believe. As noted, M2/GDP had increased by nine points three years after the FSAL. Most of that growth, moreover, was in quasi-money (time, savings, and foreign currency deposits of resident sectors other than central government). At the beginning of the period, quasimoney represented $35 \%$ of $\mathrm{M} 2$; by the end, it comprised $42 \%$. Apparently, the macro instability and high interest rates that the Bank disapproved of were not sufficient to substantially discourage intermediation. In short, the predictability of inflation may have made the macro environment more stable than it appeared at first glance. At the least, the increase in time and savings deposits suggests that a large group of savers were not overly fearful of price instability.

It was, however, the nature of this financial deepening that must have troubled Bank staff. While M2 was expanding, deposit bank credit to the private sector was declining. DBPC/GDP stood at $16.3 \%$ in the year of the loan. Three years later it was only $11.6 \%$. In other words, financial deepening was occurring, but primarily in the public banking institutions that the Bank was laboring unsuccessfully to reform. Given the institutional problems highlighted by the President's Report, it is unlikely that any additional savings implied by the surge in M2 were mobilized as efficiently as they might 
have been. It is, however, also true that annual growth in real GDP continued at $3.5 \%$. One could argue that, by re-capitalizing its ailing public banking institutions, Tanzania unwittingly propped up its rickety financial system enough to take advantage of conditions favorable to financial reform. Would the problems of these institutions recur? Probably, given the lack of institutional development. However, the Tanzanian experience suggests that, even when institutional strengthening is done poorly, favorable initial conditions may bring about post-intervention financial deepening although, as noted, that deepening may not be a very reliable indicator of financial sector health.

Tanzania and Pakistan provide an interesting contrast. Some financial deepening occurred in the wake of each of these FSALs, but for very different reasons. In the Tanzanian case, initial conditions were relatively favorable -- inflation was a bit high, but predictable; the banking sector was relatively under-developed; and the economy was relatively open to international trade. However, with respect to institutional development in the financial sector, little progress had been made. The institutional strengthening components of the FSAL, moreover, were eventually rated a failure by the Bank. In Pakistan, the reverse was true. Initial conditions were relatively unfavorable: although, in comparison with other developing countries, macro instability probably wasn't as great a problem as some of the Bank documents suggested, inflation may have been a bit less predictable than in Tanzania; international trade accounted for a smaller fraction of economic activity; and the private banking sector was better developed. The Bank gave the Government of Pakistan high marks, however, for the institutional development 
achieved both prior to and during the course of the FSAL, although a fuller assessment of the sustainability of those reforms awaits the PAR.

To be sure, three years after the FSAL, the financial deepening in each case differed -- in Tanzania, M2/GDP increased by over eight points; in Pakistan, that figure was about 2.5 points. On the basis of these cases (and the models of the previous section), it does seem reasonable to conclude, however, that institutional development can have an impact on financial deepening distinct from macro and financial sector preconditions. The results suggest that, provided some minimum level of price level stability (or predictability) is achieved, it is reasonable for the Bank to continue to devote effort both to developing an environment amenable to reform, and to actual institutional strengthening. The environmental effects may be larger, or more immediate, than the institutional, but, if possible, neither should be neglected.

\section{Conclusions}

The explosion in the Bank's (and other development banks') financial sector adjustment operations is a relatively recent phenomenon. As a result, we lack the data necessary to divine what works, at least to a degree that eliminates all doubt. As researchers, we can and should, however, evaluate this "work in progress" as the data comes in over time. Our initial inferences may subsequently require updating, but we clearly owe policy makers and major development banks even tentative conclusions. It is in this spirit that I catalogue the following observations: 
(1) Since 1990, the nature of Financial Sector Adjustment Loans (the World Bank's primary instrument for financial sector intervention) has changed slightly, but perceptibly. Although the interventions tend to focus on the same six reform areas -- interest rate distortions, prudential regulations, bank supervision, bank recapitalization, bank privatization, and non-bank financial regulations -- recapitalization, privatization, and supervision were more heavily emphasized in later interventions. Reform areas that relate less directly to the operations of banking institutions such as companies laws, capital account liberalization, and money market development have increasingly become the province of lending instruments other than the FSAL.

(2) The change in FSALs coincided with a decline in post-intervention performance as reflected in financial deepening.

(3) Declining post-intervention performance in post-1990 lending cannot be attributed solely to initial macroeconomic and financial sector conditions in the recipient country.

(4) Controlling for initial macroeconomic and financial sector conditions, certain types of reforms, especially those that dealt with prudential regulations, were associated with relatively large increases in M2/GDP. Those dealing with recapitalization have also been relatively successful, especially when they also tackled prudential regulations and/or banking supervision. However, those that focused on supervision did not, on average, substantially outperform those that did not. In addition, reform focused on bank privatization was associated with much less financial deepening three years after intervention. ${ }^{90}$

(5) Aside from reform aimed at institutional strengthening, the reform environment itself had a substantial impact on intervention outcomes. Financial deepening was positively associated with openness to trade, low inflation, and an initially under-developed financial sector. Unfortunately, unlike in the growth literature, the positive impact of openness to trade was not robust across alternative measures of trade. While, for at least one of the countries in the sample (Venezuela), it might be argued that imports as a percentage of GDP was the more reliable indicator of openness, it is troubling that the results do not also hold for exports and the Summers-Heston measure of openness to trade. More damning, perhaps, the openness result was not robust to the inclusion of observations where inflation was especially high.

90 It was, however, often unclear what form privatization actually took. In some "privatizations," only a small portion of the bank's assets are sold. In others, the bank's governing board is altered only slightly (if at all). 
(6) As the Bank's operational directives suggest, some macroeconomic stability is important for the success of financial sector interventions, especially those that incorporate interest rate liberalization.

(7) Given a minimum acceptable level of macroeconomic stability, postintervention financial deepening can be associated with either favorable initial conditions or successful institutional strengthening, or both. As the case studies indicated, slight financial deepening has occurred in instances when initial conditions were unfavorable but institutional reforms were well implemented. In other instances, institutional reform was disappointing but substantial deepening occurred on the strength of favorable initial conditions.

For the lending practitioner, these results may form the basis of more realistic expectations for projects. The financial deepening associated with some types of reform may be harder to achieve, and, in some environments, reforms may need to progress more slowly than in others. This does not, however, imply that reform should be avoided or postponed. The Bank should recognize that its efforts either to strengthen financial institutions or to provide an enabling environment for reform each appear to exert a positive influence on project outcomes. As other authors have also suggested, while it may be best to move more aggressively on financial reform when macroeconomic circumstances are favorable, "visible" reform such as interest rate de-regulation or privatization should be slowed rather than abandoned in less fortunate circumstances. By contrast, less visible institution building efforts should be continued regardless of macroeconomic conditions. ${ }^{91}$

In closing, I make a plea for better data. Reliance on changes in M2/GDP as a measure of post-intervention success is inadequate. To evaluate institution building 
efforts in the financial sector, we need to know more about post-intervention portfolio quality (su $n$ as the percent of portfolio assets that are non-performing and measures of diversification and capitalization), banking supervision (the number of supervisors, their salaries and skill levels), and governance (board composition), to name but a few major areas. In addition, firm level balance sheet, income, and production data would greatly assist researchers in evaluating the impact of financial reforms on the real sector. These more detailed measures should enable us to better assess whether change is actually taking place as a result of Bank interventions. Finally, the loan instruments themselves may be the source of some of the difficulties in achieving financial sector adjustment. That is, financial sector development is a process that may require lending instruments that disburse slowly as small steps are achieved, and that are less intimately tied to a country's balance of payments situation. Evaluating that conjecture is, however, beyond the scope of this paper as all of the interventions examined were relatively quick-disbursing and tied to balance of payments considerations. Indeed, the only way to generate the data necessary to evaluate slow-disbursing instruments may be to experiment with them. 


\section{References}

Barro, Robert J. "Economic Growth in a Cross Section of Countries," Quarterly Journal of Economics, May 1991, 106, pp. 407-44.

Bird, Graham. "Borrowing from the IMF: The Policy Implications of Recent Empirical Research," World Development, 1996, 24(11), pp. 1753-60.

Caprio Jr., Gerard; Atiyas, Izak; Hanson, James A. and Associates. Financial Reform: Theory and Practice. New York: Cambridge University Press, 1994.

Caprio Jr., Gerard and Klingebiel, Daniela. "Bank Insolvency: Bad Luck, Bad Policy, or Bad Banking?," World Bank mimeo, April, 1996.

Clague, Christopher; Keefer, Philip; Knack, Stephen and Olson, Mancur. "ContractIntensive Money: Contract Enforcement, Property Rights, and Economic Performance," Center on Institutional Reform and the Informal Sector, Univ. of Maryland, mimeo, December, 1994.

Clarke, George and Cull, Robert. "Why Privatize? The Case of Argentina's Public Provincial Banks," World Bank mimeo, June, 1997.

Cukierman, Alex and Webb, Steven. "Political Influence on the Central Bank: International Evidence," Tel Aviv University and World Bank, mimeo, 1993.

Dollar, David. "Outward-Oriented Developing Economies Really Do Grow More Rapidly: Evidence from 95 LDCs, 1976-1985," Economic Development and Cultural Change, April 1992, 40, pp. 523-44.

De Long, J. Bradford. "Productivity Growth, Convergence, and Welfare: Comment," American Economic Review, December 1988, 78, pp. 1138-54.

Gertler, Mark. "Financial Structure and Aggregate economic Activity: An Overview," Journal of Money, Credit, and Banking, August 1988, 20(3, pt. 2), pp. 559-88.

Gertler, Mark and Rose, Andrew. "Finance, Public Policy, and Growth," in Gerard Caprio Jr. et al. 1994, pp. 13-48.

King, Robert G. and Levine, Ross. "Financial Indicators and Growth in a Cross Section of Countries," World Bank mimeo, January, 1992.

King, Robert G. and Levine, Ross. "Capital Fundamentalism, Economic Development, and Economic Growth," in Carnegie-Rochester Conference Series on Public Policy, 1994, 40, pp. 259-92. 
Knack, Stephen and Keefer, Philip. "Institutions and Economic Performance: Cross Country Tests Using Alternative Institutional Measures," Economics and Politics, Nov. 1995, Z(3), pp. 207-227.

Kormendi, Roger and Meguire, Philip. "Macroeconomic Determinants of Growth: Cross Country Evidence," Journal of Monetary Economics, September 1985, 16, pp. $141-63$.

Levine, Ross and Renelt, David. "A Sensitivity Analysis of Cross-Country Growth Regressions," American Economic Review, September 1992, 82(4), pp. 942-63.

Levine, Ross. "Financial Development and Economic Growth: Views and Agenda," World Bank mimeo, October, 1996.

Mankiw, N. Gregory, Romer, David, and Weil, David. "A Contribution to the Empirics of Economic Growth," Quarterly Journal of Economics, May 1992, 152, pp. 40737.

Pritchett, Lant. "Measuring Outward Orientation in LDCs: Can It Be Done?" World Bank mimeo, 1991.

Pritchett, Lant. "Divergence, Big Time," World Bank mimeo, 1995.

Romer, Paul M. "Crazy Explanations for the Productivity Slowdown," in Stanley Fischer, ed., NBER Macroeconomics Annual, Cambridge, MA: MIT Press, 1987. pp. 163202.

Romer, Paul M. "Capital, Labor, and Productivity," Brookings Papers on Economic Activity, special issue, 1990, pp. 337-420.

Solow, Robert. "Technical Change and the Aggregate Production Function," Review of Economics and Statistics, 1957, 39, pp. 312-20. 


\begin{tabular}{|c|c|c|c|c|}
\hline \multicolumn{5}{|c|}{$\begin{array}{c}\text { Appendix } 1 \\
\text { Sample Interventions } \\
\end{array}$} \\
\hline \multicolumn{2}{|c|}{ FSALS } & \multicolumn{3}{|c|}{ Non-FSALs } \\
\hline Country & Year & Country & Year & Type-Purpose \\
\hline Albania & 1994 & Armenia & 1993 & Instit. Building \\
\hline Algeria & 1991 & Benin & 1991 & SAL II \\
\hline Argentina & 1993 & Bulgaria & 1992 & SAL I \\
\hline Bangladesh & 1990 & Burkina Faso & 1993 & Priv Sec Asst \\
\hline Bolivia & 1988 & Chile & 1988 & SAL III \\
\hline Ecuador & 1987 & China & 1993 & Fin Sec TA \\
\hline Ghana & 1991 & Costa Rica & 1985 & SAL I \\
\hline Ivory Coast & 1992 & Egypt & 1992 & Privatiz. TA \\
\hline Jamaica & 1991 & Estonia & 1995 & Fin. Instit. \\
\hline Kazakstan & 1996 & Guatemala & 1993 & EML \\
\hline Kenya & 1989 & Guyana & 1995 & Fin Sec/Bus Env \\
\hline Kyrgyz Republic & 1996 & Guinea & 1995 & Priv Sec Prom \\
\hline Mexico & 1989 & Guinea Bissau & 1987 & SAL \\
\hline Pakistan & 1989 & Honduras & 1989 & SAL I \\
\hline Peru & 1992 & Hungary & 1991 & SAL II \\
\hline Philippines & 1989 & India & 1995 & Fin Sec Dev \\
\hline Poland & 1993 & Indonesia & 1993 & Fin Sec Dev \\
\hline Rwanda & 1591 & Lao, PDR & 1989 & SAC \\
\hline Senegal & 1989 & Latvia & 1995 & EFSL \\
\hline Slovenia & 1993 & Lithuania & 1995 & EFSL \\
\hline Tanzania & 1991 & Macedonia & 1995 & FESAC \\
\hline Turkey & 1988 & Madagascar & 1990 & Fin Sec, Priv \\
\hline Uganda & 1993 & Malawi & 1991 & Ent \\
\hline Venezuela & 1990 & Mauritania & 1995 & Fin. Enter. \\
\hline & & Morocco & 1991 & Fin. \& Priv Sec \\
\hline & & Mozambique & 1994 & Fin Sec Dev. \\
\hline & & Nepal & 1989 & Fin Sec Capac. \\
\hline & & Nicaragua & $\begin{array}{l}1992 \\
1995\end{array}$ & $\begin{array}{l}\text { SAC II } \\
\text { Fcon Recov }\end{array}$ \\
\hline & & Paraguay & $\begin{array}{l}1995 \\
1994\end{array}$ & $\begin{array}{l}\text { Econ Recov } \\
\text { Priy Sec Dey }\end{array}$ \\
\hline & & Russia & $\begin{array}{l}1994 \\
1994\end{array}$ & $\begin{array}{l}\text { Priv Sec Dev } \\
\text { Fin Instit Dev }\end{array}$ \\
\hline & & Sri Lanka & 1993 & $\begin{array}{l}\text { Fin Instit Dev } \\
\text { Econ Recov }\end{array}$ \\
\hline & & Tunisia & 1992 & Priv Fin Dev \\
\hline & & Uruguay & 1989 & Econ \& Fin Ref \\
\hline \multicolumn{5}{|c|}{$\begin{array}{l}\text { Loan Type Acronyms: SAL - Structural Adjustment Loan SAC-Structural Adjustment Credit TA - } \\
\text { Technical Assistance EFSL - Enterprise and Financial Sector Loan EML - Economic Modernization } \\
\text { Loan FESAC - Financial and Enterprise Sector Adjustment Credit } \\
\text { Other Abbreviations: Ref - Reform; Capac - Capacity; Enter - Enterprise; Instit - Institutions; Recov - } \\
\text { Recovery }\end{array}$} \\
\hline
\end{tabular}




\section{Appendix 2 \\ FSALs: Changes in Size, Comprehensiveness, and Prevalence}

(1985-95)

\section{(A). Comprehensiveness and Prevalence}

Table A2.1 compares FSALs with non-FSAL financial sector adjustments undertaken by the Bank over two time periods -- pre- and post-1990. ${ }^{92}$ As one might expect, on average, FSALs cover a wider number of reform areas (roughly 6) than do non-FSALs (roughly 4). This result is robust across both time periods. Although there is somewhat more variation in the number of reform areas among non-FSALs than among FSALs, it appears safe to conclude that FSALs tend to be more comprehensive than other Bank interventions. One might expect the need for comprehensive intervention to reflect relatively poor initial conditions within a country's financial sector or, more generally, within its macroeconomic framework. However, while the average conditions at the time of the intervention are somewhat worse for FSALs than for non-FSALs, they are not strikingly so (See Appendix 6 for details).

921990 is included in the post-90 time period. The sample of non-FSAL financial sector interventions was collected by OED. While some judgment, no doubt, went into determining what constituted a non-FSAL financial sector intervention, OED endeavored to create as complete a list as possible. The comparisons here, therefore, are based on a reasonably complete summary of the Bank's financial sector activities since the mid eighties. None of the interventions identified by OED commenced prior to 1985 . A list of all the interventions is provided in Appendix 1. 


\begin{tabular}{|c|c|c|c|c|}
\hline \multicolumn{5}{|c|}{$\begin{array}{c}\text { Table A2.1 } \\
\text { FSAL Characteristics } \\
\end{array}$} \\
\hline & \multicolumn{2}{|c|}{ FSALs } & \multicolumn{2}{|c|}{$\begin{array}{c}\text { Non-FSAL } \\
\text { Financial Sector Adjustments }\end{array}$} \\
\hline & Pre- 1990 & Post- 1990 & Pre- 1990 & Post -1990 \\
\hline $\begin{array}{l}\text { Average Number } \\
\text { of Reform } \\
\text { Areas Covered by } \\
\text { Adjustment }\end{array}$ & $\begin{array}{c}6.38 \\
(1.19)^{*}\end{array}$ & $\begin{array}{c}6.43 \\
(2.24)\end{array}$ & $\begin{array}{c}4.00 \\
(2.00)\end{array}$ & $\begin{array}{c}4.74 \\
(2.36)\end{array}$ \\
\hline Minimum Areas & 5 & 2 & 2 & 2 \\
\hline Maximum Areas & 8 & 9 & 7 & 12 \\
\hline $\begin{array}{l}\text { Number of } \\
\text { Loans }\end{array}$ & 8 & 14 & 7 & 27 \\
\hline
\end{tabular}

*Standard Deviations in Parentheses

\section{(B). Importance to Recipient Country}

In contrast to initial macro- and financial sector conditions and the total number of reform areas covered by interventions (which all have remained largely unchanged), the size of the loans and the specific reform areas covered have changed quite noticeably. Although the size of the FSALs issued before 1990 was slightly larger, on average, than for the latter period, the average loan size per capita -- which is, most likely, a more accurate reflection of the importance of a given loan to a recipient country -- nearly doubled after 1990 (Table A2.2). ${ }^{93}$ In addition, within the context of a country's total funding from the Bank, FSALs assumed a substantially more important role. The typical pre-1990 FSAL represented about seven percent of the total Bank and IDA loans received

93 Average loan sizes are measured in rominal dollars which overstates the actual disparity between the earlier and later periods. After deflating the nominal figures by the United States' consumer price index, however, the changes still represent a sizable increase in real terms. If one deflates by assuming that the average pre-90 loan was issued in 1987 and that the average post-90 loan was issued in 1993, the average per capita loan 
by a country prior to the intervention; ${ }^{94}$ for post-1990 FSALs, the figure was over fourteen percent of total funding. Similarly, the average FSAL was about eight percent of total Bank/DA loans outstanding in the early period and seventeen percent in the latter one. Not only has their relative size increased, the sheer number of these interventions has also grown substantially. There were fourteen FSALs issued after 1990, only eight before. Among non-FSAL financial sector interventions, OED identified seven that began prior to the dawn of the new decade and twenty-seven that began subsequently. In short, the data indicate that financial sector interventions, especially FSALs, have become an increasingly important development tool for the Bank.

size for the earlier period, as measured in 1990 dollars, was $\$ 7.36$; for the latter it was $\$ 11.39$.

94 The total loan and credit data in Table 1.2 are taken from the "Statement of Bank Loans and IDA Credits" which accompanies the President's Report for each FSAL ("Report and Recommendation of the President of the International Bank for Reconstruction and Development and the International Development Association to the Executive Directors of the World Bank"). While similar data exist for non-FSAL interventions, many of them also covered issues outside the financial sector. To attribute the entire loan to financial sector intervention would, therefore, overstate its importance (for financial adjustment purposes) within the context of the recipient country's Bank portfolio. As a result, we compare the sizes of interventions only for FSALs. 


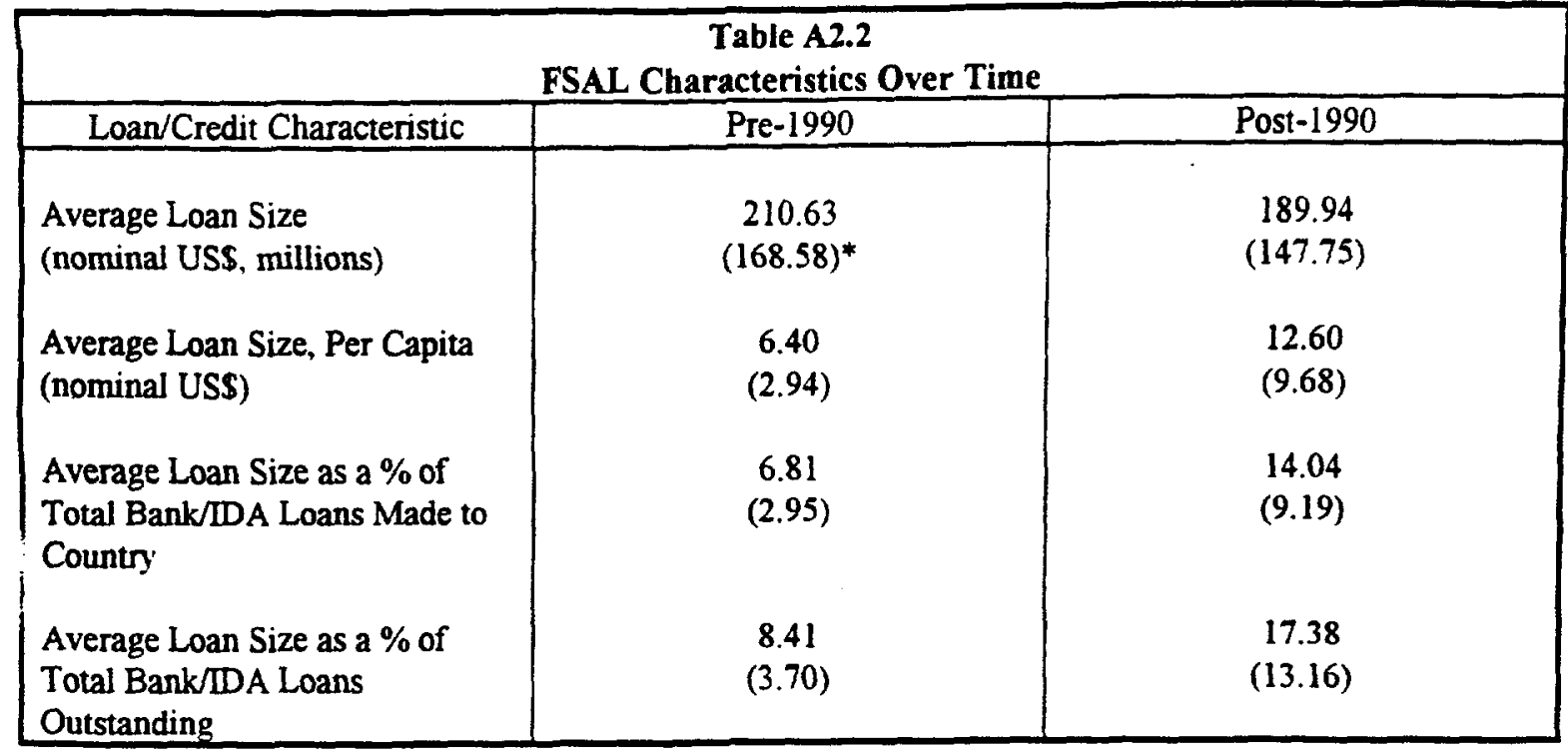

* Standard Deviations in Parentheses 


\section{Appendix 3: Changes in Emphasis \\ FSALs Versus Non-FSALs}

The groupings of reform areas for FSALs (Table 1.1) do not appear to apply perfectly to non-FSAL financial sector operations. Although, in the post-1990 period, the average probability of inclusion figure for each group exhibited the same descending order as for FSALs (from group one down to four), there was substantial variation within groups, and the differences between groups were far less pronounced. ${ }^{95}$ At least three disparities between FSALs and other interventions emerge from Table A3.1. First, for the reform areas in the ascending group (privatization, re-capitalization, and supervision), the disparities in probability of inciusion between FSALs and non-FSALs became much wider over time. In the pre-1990 period, the disparities were quite small -- re-capitalization and supervision were emphasized in FSALs and non-FSALs alike; privatization was yet to be emphasized in either type of intervention. By contrast, in the latter period, these three reform areas were among those that exhibited the widest disparities between the two intervention types. At first glance, interest rate distortions would also appear to fit this pattern. In the early period there was little disparity between the types of intervention; in the latter, the probability of inclusion in an FSAL was much higher than for a non-FSAL. However, whereas the widening disparities for the other three categories coincided with increased emphasis, in the case of interest rate distortions it coincided with substantially decreased emphasis. That is, interest rate distortions were becoming less emphasized in

95 For the post-1990 period, the average probability of inclusion for group one reform areas among the non-FSALs was $56 \%$; for group two it was $36 \%$, for three $32 \%$, for four $19 \%$. For FSALs, the figures were $83 \%$ for group one, $62 \%$ for group two, $47 \%$ for three, and $17 \%$ for four. 
both types of interventions, but that decline was especially pronounced for non-FSALs. It would be incorrect, therefore, to interpret the widening disparity between FSALs and nonFSALs with respect to this area as evidence that interest rate distortions were becoming an increasingly important component of FSALs.

A second finding to emerge from Table A3.1 is that, for the descending group of reform areas (excluding interest rate distortions), non-FSALs closed wide gaps relative to FSALs in terms of probability of inclusion. FSALs had a $31 \%$ higher probability of addressing prudential regulations than did non-FSALs in the early period. After 1990, that advantage was cut to only $15 \%$. FSALs were $59 \%$ more likely to address non-bank regulations than non-FSALs prior to 1990 , only $34 \%$ more likely thereafter. These changes were not, however, attributable to a changed emphasis in non-FSALs -- the inclusion probabilities in these categories remained nearly constant across periods. Rather, the gaps closed because of the substantially decreased emphasis on these categories among FSALs. Although not in the descending group of reforms, indirect monetary control displayed a somewhat similar pattern. Non-FSALs closed the gap on FSALs in that category by $23 \%$. Unlike prudential and non-bank regulations, however, the narrowing gap was not attributable to decreased emphasis among FSALs (the category held a constant $50 \%$ inclusion rate across periods), but to substantially increased emphasis in non-FSALs.

A third group of reforms switched from being more heavily emphasized by FSALs in the early period to being more emphasized by non-FSALs in the latter. These 
categories make it especially clear that FSALs have become increasingly focused on the reform areas in the ascending and descending groups. Rights and obligations of financial agents, companies laws, and money market development were each slightly emphasized in FSALs but never included in non-FSALs prior to 1990. After 1990, almost the reverse was true. In the most dramatic case, the rights and obligations of financial agents went from being an emphasized reform area among FSALs (38\% inclusion rate) to an emphasized area among non-FSALs (44\% inclusion rate). Although this area was not completely neglected by FSALs after 1990 ( $21 \%$ inclusion), responsibility for these reforms shifted noticeably away from them. Similar swings occurred for companies laws and money market development, although neither of those reforms were especially strong points of emphasis in either period for either type of reform. 


\begin{tabular}{|c|c|c|c|}
\hline \multicolumn{4}{|c|}{$\begin{array}{c}\text { Table A3.1 } \\
\begin{array}{c}\text { Changes in Non-FSAL Financial Sector Adjustment Operations Over Time } \\
\text { (Broken Down By Reform Area) }\end{array}\end{array}$} \\
\hline Reform Area & $\begin{array}{l}\text { Probability of Inclusion } \\
\text { Post-1990 } \\
\text { (Disparity with FSALs }_{\text {in parentheses) }}^{96} \\
\end{array}$ & $\begin{array}{l}\text { Probability of Inclusion } \\
\text { Pre- } 1990 \\
\text { (Disparity with FSALs } \\
\text { in parentheses) } \\
\end{array}$ & Change \\
\hline $\begin{array}{l}\text { Group I } \\
\text { Bank Re-Capitalization } \\
\text { Bank Supervision } \\
\text { Group II } \\
\text { Prudential Regulations } \\
\text { Non-Bank Regulations } \\
\text { Interest Rate Distortion } \\
\text { Ind. Monetary Control } \\
\text { Group III } \\
\text { Bank Privatization } \\
\text { Other Bank Ins. Reform } \\
\text { Group IV } \\
\text { Directed Credit } \\
\text { Differential Bank Reg. } \\
\text { Central Bank Law } \\
\text { Rights/Obs. Fin. Agents } \\
\text { Companies Law } \\
\text { Liberalize Capital Acct. } \\
\text { Money Market Dev. } \\
\text { Foreign Ownership }\end{array}$ & $\begin{array}{c}11 \%(-18) \\
30 \%(+1) \\
22 \%(-7) \\
44 \%(+23) \\
26 \%(+12) \\
7 \%(-7) \\
11 \%(+11) \\
4 \%(+4) \\
\\
N=27\end{array}$ & $\begin{array}{c}14 \%(-24) \\
29 \%(-9) \\
43 \%(+18) \\
0 \%(-38) \\
0 \%(-25) \\
0 \%(0) \\
0 \%(-13) \\
0 \%(0) \\
N=7\end{array}$ & $\begin{array}{c}-3 \% \\
+1 \% \\
-21 \% \\
+44 \% \\
+26 \% \\
+7 \% \\
+11 \% \\
+4 \%\end{array}$ \\
\hline
\end{tabular}

96 Disparity calculated by subtracting the reform category's non-FSAL inclusion rate from its FSAL inclusion rate. 


\begin{tabular}{|c|c|c|c|}
\hline \multicolumn{4}{|c|}{$\begin{array}{c}\text { Appendix } 4 \\
\text { Probability of Reform, Broken Down By Reform Area }\end{array}$} \\
\hline Reform Area & $\begin{array}{l}\text { Probability of Inclusion } \\
\text { in a FSAL } \\
\end{array}$ & $\begin{array}{l}\text { Probability of Inclusion } \\
\text { in a Non-FSAL }\end{array}$ & Difference \\
\hline $\begin{array}{l}\text { Areas That FSALs Are } \\
\text { Substantially More } \\
\text { Likely to Include } \\
\text { Non-Bank Fin. Regs. } \\
\text { Interest Rate Distortions } \\
\text { Bank Re-Capitalization } \\
\text { Prudential Regulations } \\
\text { Directed Credit } \\
\text { Bank Privatization } \\
\text { Ind. Monetary Control } \\
\text { Bank Supervision } \\
\end{array}$ & $\begin{array}{l}73 \% \\
68 \% \\
82 \% \\
77 \% \\
32 \% \\
36 \% \\
50 \% \\
73 \% \\
\end{array}$ & $\begin{array}{l}29 \% \\
32 \% \\
56 \% \\
56 \% \\
12 \% \\
18 \% \\
32 \% \\
59 \% \\
\end{array}$ & $\begin{array}{l}+44 \% \\
+36 \% \\
+26 \% \\
+21 \% \\
+20 \% \\
+18 \% \\
+18 \% \\
+14 \% \\
\end{array}$ \\
\hline $\begin{array}{l}\text { Areas That FSALs Are } \\
\text { Less or About As } \\
\text { Likely to Include } \\
\text { Differential Reg. Banks } \\
\text { Liberalize Capital Acct. } \\
\text { Central Banking Law } \\
\text { Other Bank Inst Reform } \\
\text { Foreign Ownership } \\
\text { Money Market Dev. } \\
\text { Rights/Obs. Fin. Agents } \\
\text { Companies Law } \\
\end{array}$ & $\begin{array}{c}32 \% \\
9 \% \\
27 \% \\
32 \% \\
0 \% \\
5 \% \\
27 \% \\
21 \% \\
\end{array}$ & $\begin{array}{c}29 \% \\
6 \% \\
26 \% \\
35 \% \\
3 \% \\
9 \% \\
35 \% \\
32 \% \\
\end{array}$ & $\begin{array}{l}+3 \% \\
+3 \% \\
+1 \% \\
-3 \% \\
-3 \% \\
-4 \% \\
-8 \% \\
-11 \% \\
\end{array}$ \\
\hline
\end{tabular}




\section{Appendix 5: FSALs vs. Non-FSALs \\ Financial Sector Indicators, 1985-95}

Although missing data problems cut the sample in half, the remaining observations make it clear that, in terms of M2/GDP, LL/GDP, ${ }^{97}$ DBPC/GDP ${ }^{98}$ and Fixed Capital Formation as a percentage of GDP (FCF/GDP), the rate of post-intervention improvement was dramatically greater for FSALs than non-FSALs (Table A5.1). In some cases, the rate of improvement for FSALs was more than four times greater than that of non-FSALs. For example, three years after the intervention, M2/GDP and FCF/GDP had increased by 4.65 and $1.51 \%$, respectively for FSALs. ${ }^{99}$ For non-FSALs, the figures were 0.95 and $0.28 \%$. Similar results obtain for LL/GDP. While non-FSALs, on average, have had a positive (if more muted) impact than FSALs with respect to those three variables, there has been hardly any improvement with respect to DBPC/GDP $(.05 \%)$. By contrast, the average improvement in DBPC/GDP in the wake of an FSAL was $2.85 \%$.

With respect to central bank credit to the private sector as a percentage of GDP (CB/GDP), there is also a marked disparity between FSALs and non-FSALs. Presumably, a high percentage reflects substantial state involvement in credit markets which is likely to have adverse effects on capital allocation. The successful intervention would, therefore, reduce this figure. On this measure, however, non-FSALs have outperformed FSALs. For non-FSALs the reduction in CB/GDP was $0.81 \%$ three years after the typical

\footnotetext{
97 Liquid liabilities as a percentage of GDP.

98 Deposit bank claims on the private sector as a percentage of GDP.

99 Improvements are relative to initial conditions which were computed as the average of the year of the intervention and the prior year.
} 
intervention; for FSALs there was almost no reduction (.06\%). The disparity may be reflective of the differential focus of the two types of interventions. Recall that, among non-FSALs, central bank reform was much more prevalent than among FSALs prior to 1990. On average, neither type of reform has had success in increasing private credit issued by non-bank financial intermediaries as a percentage of GDP (NB/GDP).

\begin{tabular}{|c|c|c|c|c|}
\hline \multicolumn{5}{|c|}{$\begin{array}{c}\text { Table A5.1 } \\
\text { Performance Indicators, FSALs vs. Non-FSALs }\end{array}$} \\
\hline Indicator & \multicolumn{2}{|c|}{$\begin{array}{c}\text { FSALs } \\
(\% \text { Change })\end{array}$} & \multicolumn{2}{|c|}{$\begin{array}{l}\text { Non-FSALs } \\
\text { (\% Change) }\end{array}$} \\
\hline & $\begin{array}{l}3 \text { Yrs. After } \\
\text { Intervention }\end{array}$ & $\begin{array}{l}\text { Measured by } \\
\text { Indicator's } \\
\text { Avg. Level in } \\
\text { the } 3 \text { yrs. } \\
\text { after the } \\
\text { project }\end{array}$ & $\begin{array}{l}3 \text { Yrs. After } \\
\text { Intervention }\end{array}$ & $\begin{array}{l}\text { Measured by } \\
\text { Indicator's } \\
\text { Avg. Level in } \\
\text { the } 3 \text { yrs. } \\
\text { after the } \\
\text { project }\end{array}$ \\
\hline M2 as $\%$ of gdp & $+4.65(\mathrm{~N}=12)$ & $+2.80(\mathrm{~N}=12)$ & $+0.95(\mathrm{~N}=13)$ & $+1.09(\mathrm{~N}=13)$ \\
\hline Liquid Liabilities as $\%$ of gdp & $+4.87(\mathrm{~N}=9)$ & $+3.22(\mathrm{~N}=9)$ & $+2.99(\mathrm{~N}=7)$ & $+1.29(\mathrm{~N}=13)$ \\
\hline Dep Bank Priv Cred as \% of gdp & $+2.85(\mathrm{~N}=12)$ & $+1.48(\mathrm{~N}=12)$ & $+0.05(\mathrm{~N}=12)$ & $-0.59(\mathrm{~N}=12)$ \\
\hline Non Bank Priv Cred as \% of gdp & $-0.41(N=12)$ & $-0.22(\mathrm{~N}=12)$ & $-0.27(\mathrm{~N}=11)$ & $-0.22(\mathrm{~N}=11)$ \\
\hline Cen Bank Priv Cred as \% of gdp & $-0.06(N=12)$ & $-0.04(\mathrm{~N}=12)$ & $-0.81(\mathrm{~N}=12)$ & $-0.76(\mathrm{~N}=12)$ \\
\hline Fixed Cap. Form. as $\%$ of gdp & $+1.51(\mathrm{~N}=13)$ & $+0.98(\mathrm{~N}=13)$ & $+0.28(\mathrm{~N}=13)$ & $+0.43(\mathrm{~N}=13)$ \\
\hline
\end{tabular}

Although the IFS data are especially sketchy in this area, FSALs and non-FSALs alike appear to have had some success in correcting interest rate distortions. Three years after intervention, real deposit rates had increased by an average of $37 \%$ in the six FSAL countries in which they were originally negative; the increase left four of the countries with a positive real deposit rate, all but one of those in the $0-5 \%$ range (Venezuela's rate was $15 \%$ ). Another of the six, Turkey, maintained a negative real deposit rate but showed substantial improvement (from $-14 \%$ to $-3 \%$ ). Only Ecuador showed no improvement (moving from $-3 \%$ to $-5 \%$ ). In the three non-FSAL countries where rates were negative at the time of intervention, increases averaged a whopping $495.2 \%$. That average masks substantial variation. Two of the countries (Hungary and Benin) experienced five to seven 
percent increases; Nicaragua had a $1472.7 \%$ increase. After their moderate increases, Hungary and Benin had real interest rates of $1.4 \%$ and $2.6 \%$, respectively; Nicaragua's remarkable improvement left it with a $0.3 \%$ real deposit rate. Although data is available for only nine cases in which real deposits were severely repressed, the improvements after both types of interventions were substantial. It may be that correcting interest rate distortions, a point of emphasis in early interventions, is a reform for which bank interventions are especially well-suited regardless of their type. However, with respect to deposit bank credit to the private sector and a number of other general indicators of depth in the financial sector, the typical FSAL appears to have out-performed the typical nonFSAL. While it appears that neither type of intervention has been particularly effective in increasing non-bank financial intermediation, non-FSALs have been slightly more effective in one area -- reducing central bank credit to the private sector. ${ }^{100}$

100 As described in the text, however, the Chilean observation is largely responsible for this last result. 


\section{Appendix 6: Initial Financial Sector and Macroeconomic Conditions FSAL Recipients Versus Non-FSAL Recipients}

Initial financial conditions as measured by deposit banks' credit to the private sector as a percentage of GDP (DBPC/GDP) and the ratios of both M2 and liquid liabilities to GDP (M2/GDP and LL/GDP, respectively) indicate that FSALs were typically undertaken in countries with slightly less developed financial sectors than in non-FSAL countries. ${ }^{101}$ The figures for non-FSAL countries, however, are driven by two observations, Egypt and China. Those are the only two countries that produced a DBPC/GDP, M2/GDP, or LL/GDP figure higher than 67\%. China's M2/GDP figure was 95.8\%; its LL/GDP was $89.5 \%$. Egypt's LL/GDP was $86.5 \%$; its M2/GDP was $84.5 \%$. For reference, the sample averages were $32.5 \%$ for M2/GDP, $21.6 \%$ for DBPC/GDP, and $30.1 \%$ for LL/GDP. Substantial state involvement in China's banking sector makes it unlikely that the figures derived from the IMF data are reflective of a developed financial sector, at least not in a typical free market sense. With respect to Egypt, the Bank has noted previously that their high financial ratios are not reliable indicators of a developed

101 The source of the DBPC, M2, LL, and GDP data is the IMF's International Financial Statistics Yearbook (1996). DBPC includes all assets of deposit money banks classified as claims on the private sector. M2 includes the sum of all currency held outside of banks, demand deposits other than those of the central government, and time, savings, and foreign currency deposits of "resident sectors other than the central government." Liquid liabilities include M2 plus demand and interest bearing liabilities of non-bank financial intermediaries such as savings banks, postal savings institutions, and finance companies. In the individual country data, DBPC data are reported on line 22d, M2 data on line 351, and LL data on 551. The macroeconomic, interest rate, and population data used in this study are also drawn from these country tables. For many of the countries that received financial sector assistance from the Bank, some of this data is missing. As a result, the number of observations in the FSAL vs. non-FSAL categories is not necessarily consistent across indicators (see Table A6.1, for example). 
financial sector. Rather, much like in many socialist economies, high M2/GDP and LL/GDP figures represent a "monetary overhang" born of severe financial repression. ${ }^{102}$ Egypt's DBPC/GDP figure of only $22 \%$ (far closer to the sample average) is clearly a much more accurate reflection of the state of development of its financial sector. When the non-FSAL figures are re-computed excluding both China and Egypt, there is much less to choose from in terms of average initial financial sector conditions between the two types of interventions -- the deposit bank private credit figures are about $20 \%$ for each sub-sample, the M2 and liquid liabilities figures about $30 \%$.

With respect to average macroeconomic conditions at the time of the intervention, comparisons between the FSAL and non-FSAL samples are also inconclusive. Whereas the average growth rate in real GDP was slightly higher (4.4\% versus $3.1 \%)$ and the inflation rate slightly lower (18\% versus $25 \%$ ) among the non-FSAL countries, the current account deficit among FSAL countries tended to be somewhat lower (3.0\% versus $5.8 \%)$. Admittedly, there is substantial variation in initial macroeconomic conditions among the non-FSAL countries (as indicated by the relatively large sample standard deviations). This clouds the interpretation of the averages somewhat; however, it appears doubtful that the relatively comprehensive nature of FSALs can be attributed solely to poor initial conditions -- either financial or macroeconomic -- in the recipient country. Moreover,

102 "Egypt: Financial Policy for Adjustment and Growth," Volume I (Policy Environment), World Bank, Country Operations, Middle East and North Africa Region, (1993), p. 3. 
similarities in initial conditions among FSAL and non-FSAL countries persisted across

both time periods (pre- and post-1990). ${ }^{103}$

\section{Table A6.1}

Average Conditions at Time of Intervention, FSALs vs. Non-FSALs

\begin{tabular}{|c|c|c|c|}
\hline Variable & FSALs & \multicolumn{2}{|c|}{$\begin{array}{c}\text { Non-FSAL Financial Sector } \\
\text { Adjustments }\end{array}$} \\
\hline Financial Sector Conditions & Full Sample & Full Sample & $\begin{array}{l}\text { Outliers } \\
\text { Omitted }^{104}\end{array}$ \\
\hline $\begin{array}{l}\text { Deposit Bank Credit as a \% of } \\
\text { GDP }\end{array}$ & $\begin{array}{l}18.24 \% \\
(9.47) \\
N=21\end{array}$ & $\begin{array}{l}24.85 \% \\
(19.12) \\
\mathrm{N}=22\end{array}$ & $\begin{array}{l}21.75 \% \\
(12.84) \\
N=21\end{array}$ \\
\hline $\mathrm{M} 2$ as a $\%$ of GDP & $\begin{array}{c}26.85 \% \\
(10.75) \\
N=21\end{array}$ & $\begin{array}{c}37.73 \% \\
(21.87) \\
N=23\end{array}$ & $\begin{array}{c}32.74 \% \\
(14.89) \\
N=21\end{array}$ \\
\hline Liquid Liabilities as a $\%$ of GDP & $\begin{array}{c}27.44 \% \\
(13.86) \\
N=13\end{array}$ & $\begin{array}{c}33.02 \% \\
(25.02) \\
\mathrm{N}=12\end{array}$ & $\begin{array}{c}28.16 \% \\
(19.38) \\
N=11\end{array}$ \\
\hline \multicolumn{4}{|l|}{ Macroeconomic Conditions } \\
\hline GDP Growth Rate & $\begin{array}{c}3.14 \\
(3.65) \\
N=17\end{array}$ & \multicolumn{2}{|c|}{$\begin{array}{c}4.39 \\
(5.05) \\
N=23\end{array}$} \\
\hline Inflation & $\begin{array}{l}25.13 \% \\
(20.64) \\
N=21\end{array}$ & \multicolumn{2}{|c|}{$\begin{array}{c}18.38 \% \\
(25.83) \\
N=26\end{array}$} \\
\hline $\begin{array}{l}\text { Current Account Surplus/Deficit } \\
\text { as a } \% \text { of GDP }\end{array}$ & $\begin{array}{l}-2.99 \\
(5.94) \\
N=21\end{array}$ & \multicolumn{2}{|c|}{$\begin{array}{c}-5.79 \\
(12.24) \\
N=21\end{array}$} \\
\hline
\end{tabular}

* Standard Deviations in Parentheses

103 For example, among FSAL countries the average DBPC/GDP was $19.5 \%$ prior to 1990 and $17.5 \%$ thereafter. Prior to 1990 , the non-FSAL country average was $23.1 \%$; post-90 it was $21.2 \%$. Although the post-90 FSAL countries do have the lowest average initial development, the disparities are again not particularly striking. Indeed, the regression results presented below indicate that these disparities explain only a portion of the variation in outcomes.

104 Observations for China and Egypt were omitted as described above in the text. 


\section{Appendix 7a. \\ Construction of Institutional Indices}

(ICRG)

\section{ICRG Indicators}

Quality of the Bureaucracy:

High scores indicate "autonomy from political pressure" and "strength and expertise to govern without drastic changes in policy or interruptions in government services"; also existence of an "established mechanism for recruiting and training." Scored 0-6.

\section{Corruption in Government:}

Lower scores indicate "high government officials are likely to demand special payments" and "illegal payments are generally expected throughout lower levels of government" in the form of "bribes connected with import and export licenses, exchange controls, tax assessment, policy protection, or loans." Scored 0-6.

\section{Rule of Law:}

This variable "reflects the degree to which the citizens of a country are willing to accept the established institutions to make and implement laws and adjudicate disputes." Higher scores indicate "sound political institutions, a strong court system, and provisions for an orderly succession of power." Lower scores indicate "a tradition of depending on physical force or illegal means to settle claims." Upon changes in government in countries scoring low on this measure, new leaders "may be less likely to accept the obligations of the previous regime. Original variable name in ICRG is "law and order tradition." Scored $0-6$.

\section{Expropriation Risk:}

Assessment of risk of "outright confiscation" or "forced nationalization." Scored 0-10, with lower scores for higher risks.

\section{Repudiation of Contracts by Government:}

Indicates the "risk of a modification in a contract taking the form of a repudiation, postponement, or scaling down" due to " budget cutbacks, indigenization pressure, or a change in government economic and social priorities." Scored $0-10$, with lower scores for higher risks.

\section{ICRG Index:}

The sum of the preceding five variables, with the first three transformed into ten-point scales.

Source: Knack and Keefer (1995), pp. 225-6. 


\section{Appendix $7 \mathrm{~b}$. \\ Construction of Institutional Indices \\ (BERI)}

\section{BERI Indicators}

\section{Bureaucratic Delays:}

Measures the "speed and efficiency of the civil service including processing customs clearances, foreign exchange remittances and similar applications." Scored 0-4, with higher scores for greater efficiency.

\section{Nationalization Potential:}

Measures risk of "expropriation for no compensation" and "preferential treatment for nationals." Scored 0-4, with higher scores for lower risks.

\section{Contract Enforceability:}

Measures the "relative degree to which contractual agreements are honored and complications presented by language and mentality differences." Scored $0-4$, with higher scores for greater enforceability.

\section{Infrastructure Quality:}

Assesses "facilities for and ease of communication between headquarters and the operation, and within the country," as well as quality of transportation. Scored 0-4, with higher scores for superior quality.

\section{BERI Index:}

Sum of the preceding four variables.

Source: Knack and Keefer (1995), p. 226. 


\begin{tabular}{|c|c|c|c|c|}
\hline \multicolumn{5}{|c|}{$\begin{array}{c}\text { Appendix } 8 \\
\text { Post-Intervention Change in M2/GDP, Regression Results } \\
\text { Re-Capitalization, Supervision, and Prudential Regulations }\end{array}$} \\
\hline \multirow[t]{2}{*}{$\begin{array}{l}\text { Explanatory } \\
\text { Variable }\end{array}$} & \multicolumn{2}{|c|}{$\begin{array}{l}\text { Macro + Financial + Trade + Bank } \\
\text { Supervision + Re-Capitalization }\end{array}$} & \multicolumn{2}{|c|}{$\begin{array}{l}\text { Macro + Financial + Trade } \\
\text { + Prudential Regulations + Re- } \\
\text { Capitalization }\end{array}$} \\
\hline & (25) & (26) & (27) & (28) \\
\hline Constant & $\begin{array}{l}-9.83 \\
(1.51)\end{array}$ & $\begin{array}{c}-6.72 \\
(1.77)\end{array}$ & $\begin{array}{l}-9.80 \\
(1.50)\end{array}$ & $\begin{array}{l}-6.75 \\
(1.79)\end{array}$ \\
\hline Group 1 & 5.57 & & 5.47 & \\
\hline & (1.35) & & $(1.32)$ & \\
\hline Group 2 & $\begin{array}{c}2.11 \\
(0.48)\end{array}$ & & $\begin{array}{c}2.18 \\
(0.49)\end{array}$ & \\
\hline Group 3 & $\begin{array}{c}1.32 \\
(0.29)\end{array}$ & & $\begin{array}{c}1.35 \\
(0.30)\end{array}$ & \\
\hline DBPC/GDPx Infl. & & $\begin{array}{r}-.0040 \\
(1.40)\end{array}$ & & $\begin{array}{r}-.0038 \\
(1.22)\end{array}$ \\
\hline IMP/GDP & $\begin{array}{c}0.29 \\
(1.79)\end{array}$ & $\begin{array}{l}0.36 \\
(2.49)\end{array}$ & $\begin{array}{l}0.29 \\
(1.78)\end{array}$ & $\begin{array}{c}0.36 \\
(2.43)\end{array}$ \\
\hline $\begin{array}{l}\text { Re-Capitalization } \\
\text { Only }\end{array}$ & $\begin{array}{c}2.32 \\
(0.82)\end{array}$ & $\begin{array}{c}2.93 \\
(1.01)\end{array}$ & $\begin{array}{c}2.42 \\
(0.64)\end{array}$ & $\begin{array}{c}2.24 \\
(0.57)\end{array}$ \\
\hline $\begin{array}{l}\text { Re-Capitalization } \\
\text { w/ Supervision }\end{array}$ & $\begin{array}{l}3.38 \\
(1.77)\end{array}$ & $\begin{array}{l}2.75 \\
(1.34)\end{array}$ & & \\
\hline $\begin{array}{l}\text { Re-Capitalization } \\
\text { w/ Prud. Regs. }\end{array}$ & & & $\begin{array}{c}3.25 \\
(1.73)\end{array}$ & $\begin{array}{c}2.91 \\
(1.42)\end{array}$ \\
\hline Adj. R-Squared & .433 & .335 & .426 & .337 \\
\hline $\begin{array}{l}\text { Number of } \\
\text { Observations }\end{array}$ & 16 & 16 & 16 & 16 \\
\hline
\end{tabular}

Note: t-statistics in parentheses; group dummies defined in Table 2.2. 


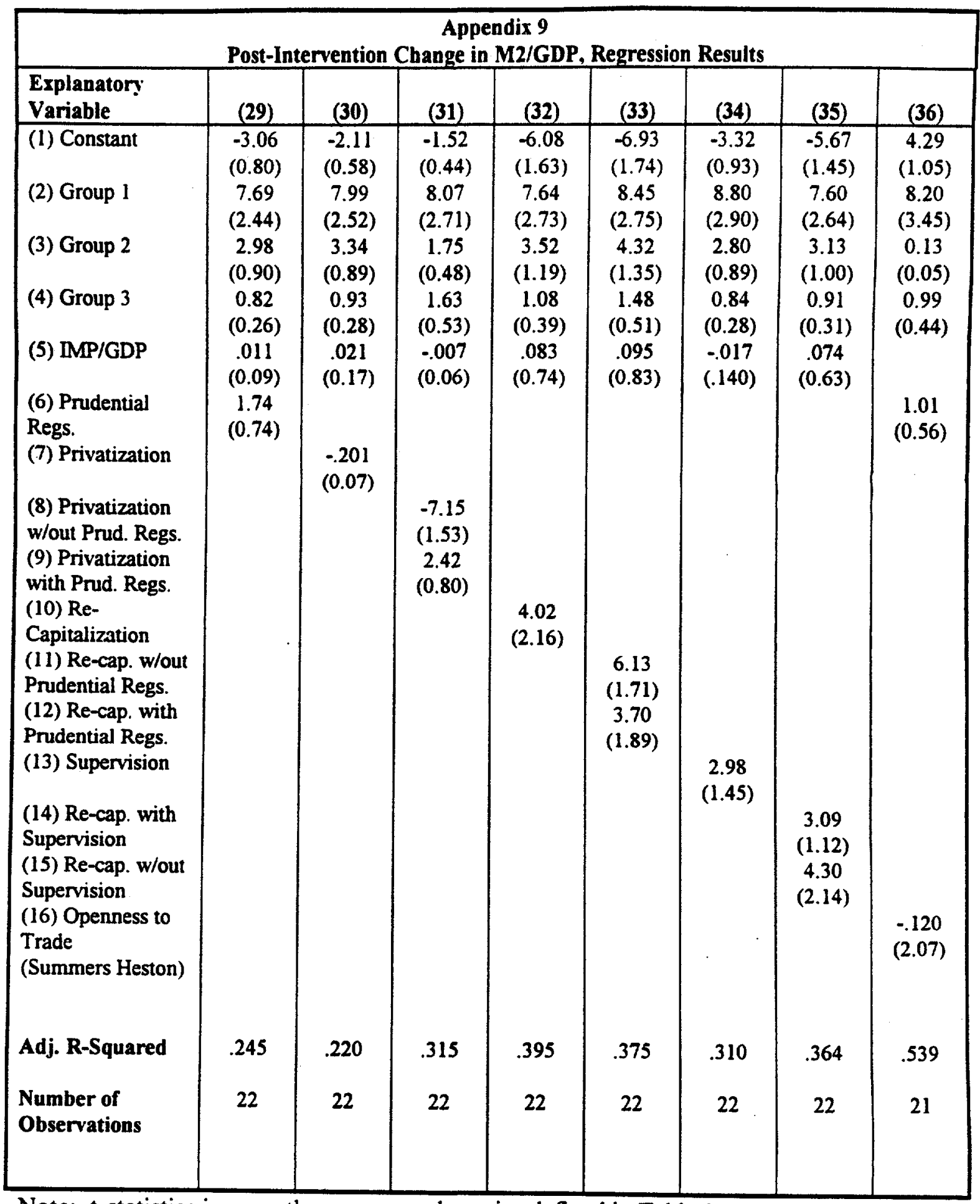

Note: $\mathrm{t}$-statistics in parentheses; group dummies defined in Table 2.2. 
Figure 1 Change in Financial Depth from Financial Sector Interventions

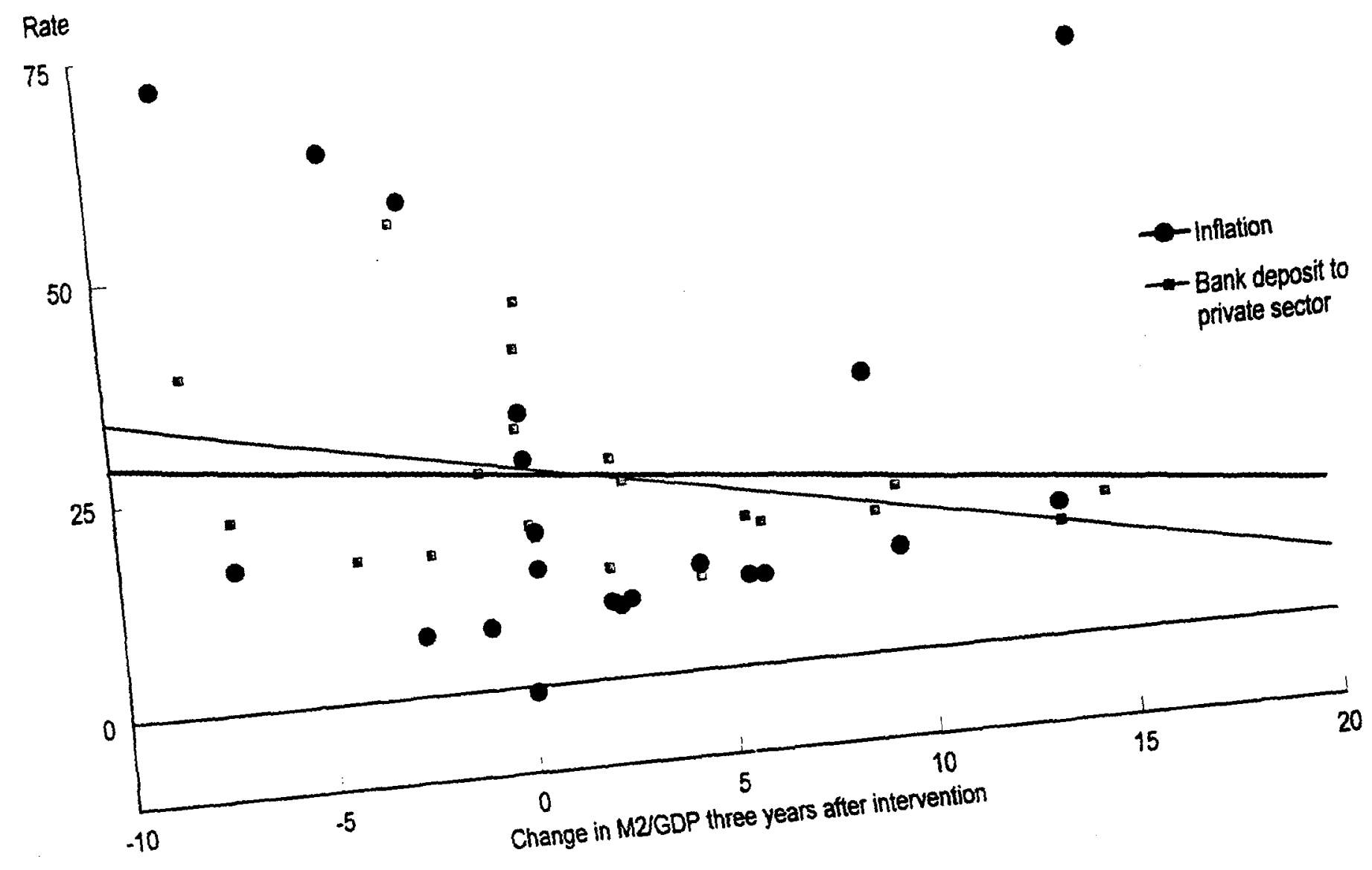


Figure 2 Financial Sector Reforms in Selected Bank Projects

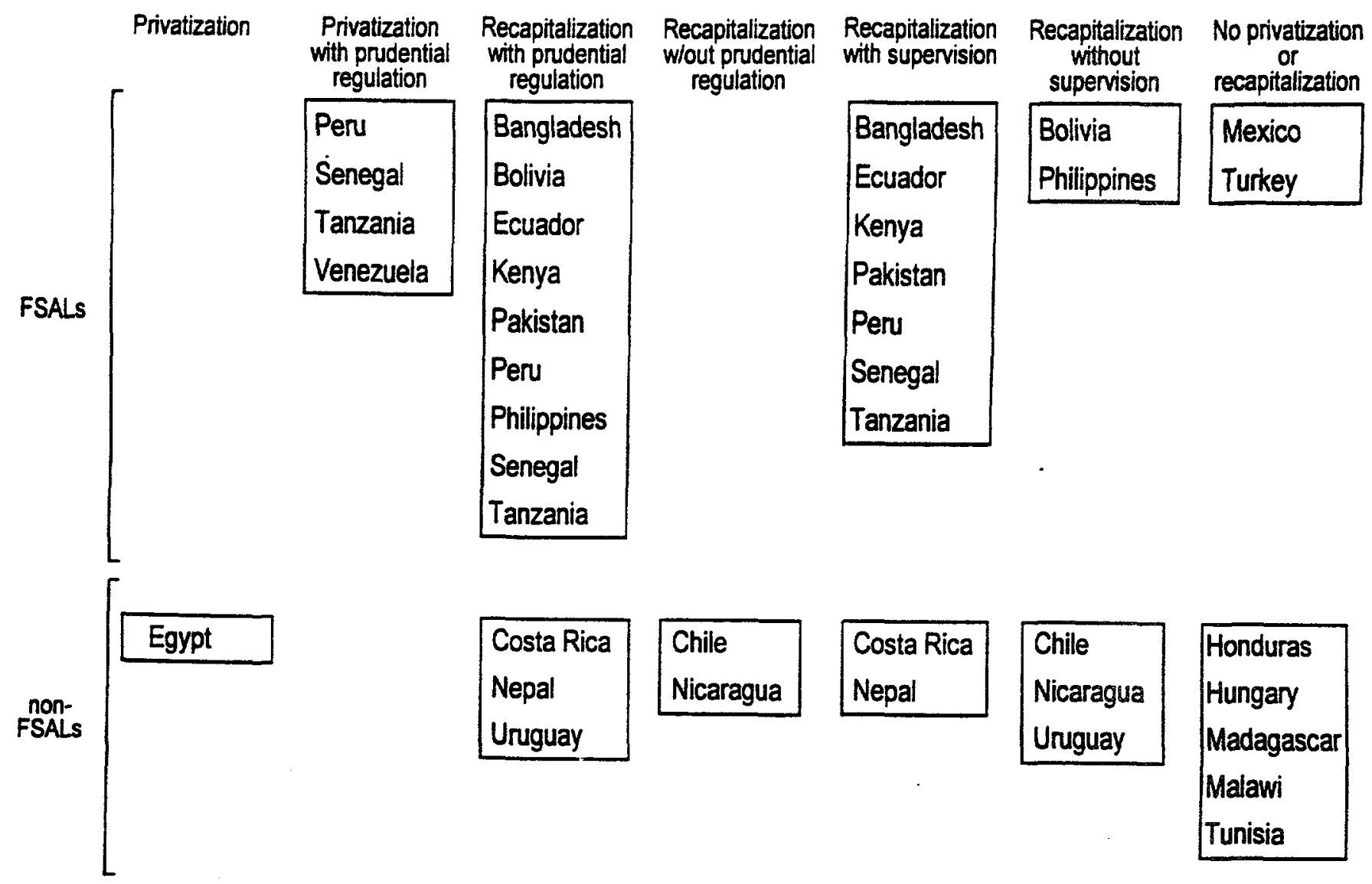


Figure 3 Financial Sector Performance: Form of Intervention and Change in M2/GDP

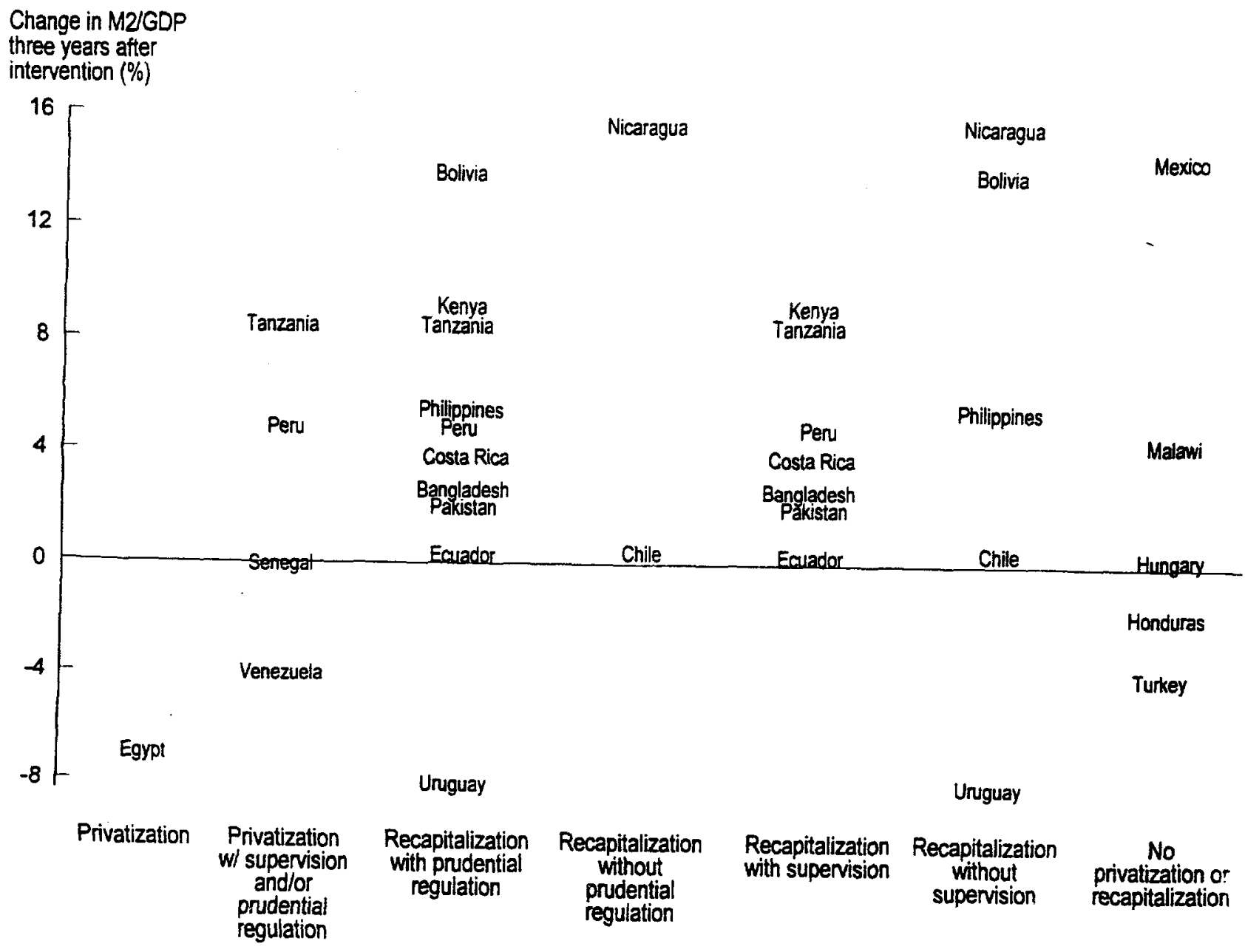


Title

WPS1787 Trading Arrengements and indugtrial Develophent

WPS1788 An Eononic Anaysis of Woodfuel Managemen in the Sanel: The Case of ched

WPS1789 Compatition iaw in Bugaria Ater Central Planning

WPS1790 Interoreting the Gomient of Schoolng in the Huran Capital Eamings Funwim

WPS1791 Toward Beter Fegulation of Private Pension Funds

WPS1792 Tradeofs from Hedging: Oif Price Risk in Ecuador

WPS1793 Wage ard Panion Prasura on the Polsh ouger

WPS1794 Ownership Strucure Corporate Governence, and Corporate Periomans: The cave of chinese Stock Comprnis

WPS1795 What Eductional Production Functions Realy STbw A Positue Theory of sucation Spending

WPS1796 Cents and Soclabily: Household Income and Sovia capital in Rura! Tanzente

WPS1797 Fontal and Inomai Regulation of Industrit Polution:

Comparatve Evidence from Indonesia and the United States

WPS1798 Poor Areas, Or Only Porn Dople?

WPS1799 More for tha Popr Is Less for the Poor: The Politics of Tapgeting

WPS1800 Single-Esuavo Estmation of tho Equibnum Puar Exchange Rata มูushor

Diego Puga

Anthony J. Venables

Kennerin M. Chomitz

Charles Grimiths

Bernard Hoekman

Simeon Djankov

Barry R. Chiswick

Date

June 1997

June 1997

Contact

for paper

J. Ngaine

37947

A. Maranon 39074

June 1997

J. Ngaine

37947

June 1997

P. Singh

85631

Hemant Shah

June 1997

N. Johi

38613

Sudhakar Satyanarayan

June 1997

E. Somensatto 30128

Alain de Crombrugghe

June 1997

M. Jandu

33103

Xiaonian $X_{u}$

June 1997

J. Chinsen

34022

Iant Pritchett

Deon Filmer

July 1997

S. Fallon 38009

Deepa Narayan

Lant Pritchett

July 1997

S. Fallon

38009

Sheoli Pargal hemamala Hettige

Manjula Singh

David Wheeler

Martin Ravalion

Quentin Wodon

Joneth B. Geibach

Lant H. Pritchett

whh Beffes

brahim A. Elbadawi

Stephen A. O'Connell
July 1997

E. de Castro

89121

July 1997

P. Sader 33902

July 1997

S. Fallen 38009

August 1997

P. Kokila

33716 
Policy Research Working Paper Series

Title

WPS1801 Regional Integration as Diplomacy

WPS1802 Are There Synergies Between World Bank Partial Credit

Guarantees and Private Lending?

WPS1803 Fiscal Adjustments in Transition

Economies: Social Transfers and the Alain de Crombrugghe Efficiency of Public Speriding: A Comparison with OECO Countries
Asthor

Maurice Schiff

- Alan Winters

Harry Huizinga

Date

August 1997

August 1997

Bartara Fakin
Contact for paper

J. Ngaine 37947

P. Sintim-Aboagye 38526

M. Jandu

33403 